University of Tennessee Health Science Center UTHSC Digital Commons

$12-2008$

\title{
Synthesis and Evaluation of Tetramic Acids as Antimicrobial Agents
}

Jason B. Wilson

University of Tennessee Health Science Center

Follow this and additional works at: https://dc.uthsc.edu/dissertations

Part of the Medicinal and Pharmaceutical Chemistry Commons, and the Pharmaceutics and Drug Design Commons

\section{Recommended Citation}

Wilson, Jason B. , "Synthesis and Evaluation of Tetramic Acids as Antimicrobial Agents" (2008). Theses and Dissertations (ETD). Paper 367. http://dx.doi.org/10.21007/etd.cghs.2008.0354.

This Thesis is brought to you for free and open access by the College of Graduate Health Sciences at UTHSC Digital Commons. It has been accepted for inclusion in Theses and Dissertations (ETD) by an authorized administrator of UTHSC Digital Commons. For more information, please contact jwelch30@uthsc.edu. 


\title{
Synthesis and Evaluation of Tetramic Acids as Antimicrobial Agents
}

\begin{abstract}
As bacterial infectious diseases are a major cause of morbity and mortality throughout the world, and many causative organisms are resistant to currently available antibiotics, the motivation for the development of new drugs is readily apparent. A number of natural products exhibiting antimicrobial activity possess a tetramic acid (2,4-pyrrolidinedione) functional group. As their antibacterial mechanism of action is different from that of many of the currently available antibiotics, these compounds have potential to serve as a basis for a pharmacophore in synthetic compounds. However, toxicity to eukaryotic cells is frequently a problem with currently known tetramic acids. The purpose of the project, as outlined in the following pages, is to demonstrate a method of synthesis of a small library of compounds containing the tetramic acid ring, and to illustrate their structure-activity relationship as agents both having activity against Gram-positive bacteria and possessing low hemolytic activity. Chapter One takes an overview of a number of the different classes of antibiotics available today, with emphasis on their method of action, then covers several naturally occurring tetramic acid compounds with antibiotic activity, and finally methods of synthesis. Chapter Two details the methods used to synthesize and characterize the set of compounds and examines their activity against a set of Gram-positive bacteria, with the purpose of clarifying their structure-activity relationship.
\end{abstract}

\section{Document Type}

Thesis

Degree Name

Master of Science (MS)

Program

Pharmaceutical Sciences

Research Advisor

Richard E. Lee, Ph.D.

\section{Keywords}

Antibiotics, antimicrobials, pyrrolidine, tetramic

\section{Subject Categories}

Medicinal and Pharmaceutical Chemistry | Medicine and Health Sciences | Pharmaceutics and Drug Design | Pharmacy and Pharmaceutical Sciences 


\title{
SYNTHESIS AND EVALUATION OF TETRAMIC ACIDS AS ANTIMICROBIAL AGENTS
}

\author{
A Thesis \\ Presented for \\ The Graduate Studies Council \\ The University of Tennessee \\ Health Science Center
}

In Partial Fulfillment

Of the Requirements for the Degree

Master of Science

From The University of Tennessee

By

Jason B. Wilson

December 2008 
Copyright (C) 2008 by Jason Brett Wilson

All rights reserved 


\section{Dedication}

This thesis is dedicated to my parents

Mary Jeanne Dismuke

Joseph C. Dismuke

and John R. Wilson 


\section{Acknowledgments}

I wish to acknowledge the guidance of my advisor, Dr. Richard Lee, for his oversight during the synthetic projects I have undertaken during my time in graduate school. I thank my committee members, Dr. John K. Buolamwini and Dr. Mark A. Miller, as well for their suggestions in completing this thesis. I also wish to thank Dr. Julian Hurdle for help in revising the introductory section and for performing the microbiological testing. Thanks also goes to Dr. Raghunandan Yendapally for working with me through the first compound I synthesized in the series, and to Dr. Dianqing Sun for assisting me with difficult spots in the synthetic processes. I want to thank my parents for their financial and moral support throughout my graduate studies and writing as well, and my brother Matt Wilson for knowing what to say at critical points. I would most likely not have completed this process without you all. 


\begin{abstract}
As bacterial infectious diseases are a major cause of morbity and mortality throughout the world, and many causative organisms are resistant to currently available antibiotics, the motivation for the development of new drugs is readily apparent. A number of natural products exhibiting antimicrobial activity possess a tetramic acid $(2,4-$ pyrrolidinedione) functional group. As their antibacterial mechanism of action is different from that of many of the currently available antibiotics, these compounds have potential to serve as a basis for a pharmacophore in synthetic compounds. However, toxicity to eukaryotic cells is frequently a problem with currently known tetramic acids. The purpose of the project, as outlined in the following pages, is to demonstrate a method of synthesis of a small library of compounds containing the tetramic acid ring, and to illustrate their structure-activity relationship as agents both having activity against Grampositive bacteria and possessing low hemolytic activity. Chapter One takes an overview of a number of the different classes of antibiotics available today, with emphasis on their method of action, then covers several naturally occurring tetramic acid compounds with antibiotic activity, and finally methods of synthesis. Chapter Two details the methods used to synthesize and characterize the set of compounds and examines their activity against a set of Gram-positive bacteria, with the purpose of clarifying their structureactivity relationship.
\end{abstract}




\section{Table of Contents}

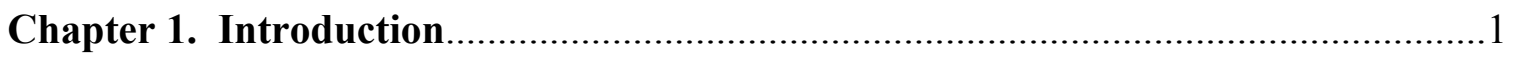

Current Antibiotics Used to Treat Skin and Soft Tissue Infections................................ 2

Inhibitors of Bacterial Cell Wall Synthesis ............................................................ 2

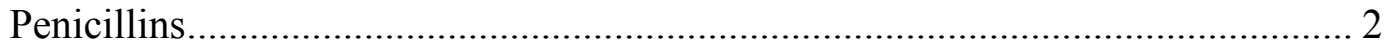

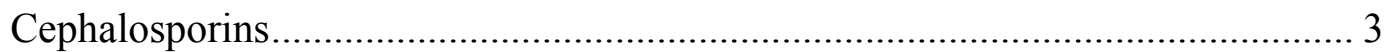

Peptide-Based Cell Wall Inhibitors .............................................................. 5

Protein Biosynthesis Inhibitors ......................................................................... 5

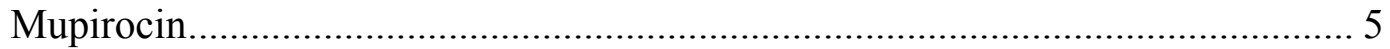

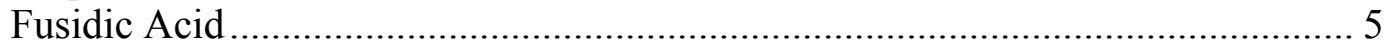

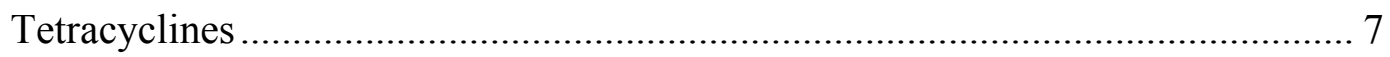

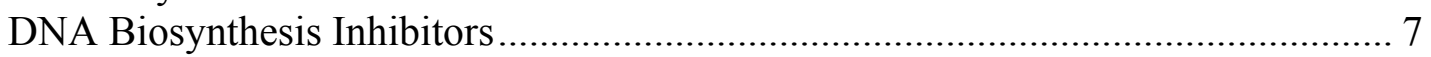

Membrane-Destabilizing Agents ...................................................................... 7

Naturally-Occurring Tetramic Acids ..................................................................... 9

Tetramic Acid Structure-Activity Relationship Investigations...................................... 11

Synthetic Methods for Tetramic Acids …………................................................. 12

Reutericyclin Properties and Synthetic Approaches .................................................... 15

\section{Chapter 2. Synthesis, Characterization, and Evaluation of Substituted Tetramic} Acid Compounds as Antibacterial Agents..........................................18

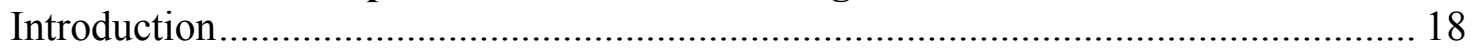

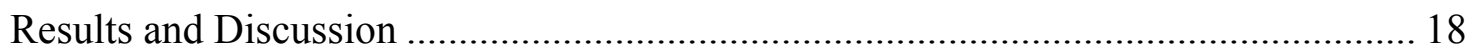

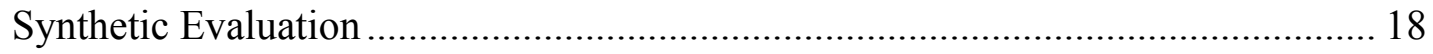

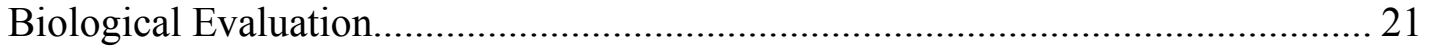

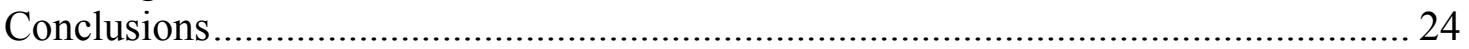

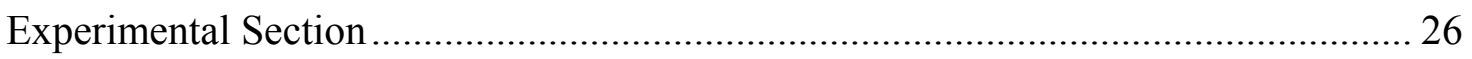

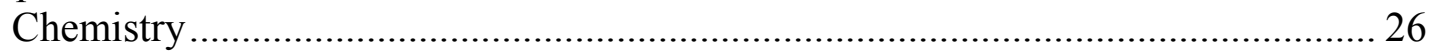

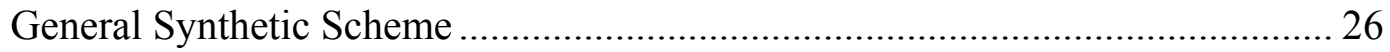

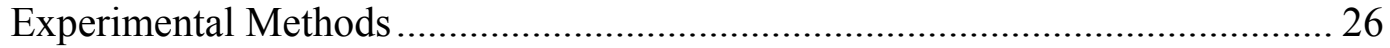

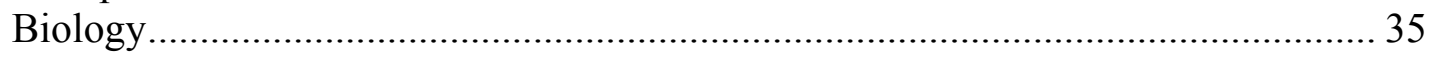

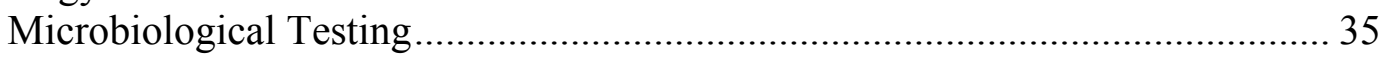

Hemolysis Assay ....................................................................................... 35

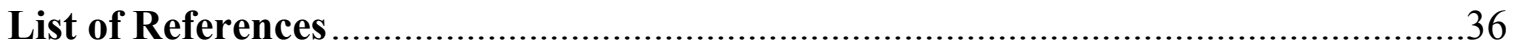

Vita 


\section{List of Figures}

Figure 1.1 Earliest Penicillins ...............................................................................

Figure 1.2 Modified Penicillins .........................................................................4

Figure 1.3 General Structure of Cephalosporins ......................................................

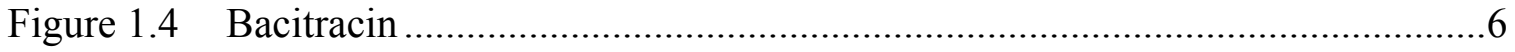

Figure 1.5 Mupirocin.......................................................................................

Figure 1.6 Fusidic Acid ......................................................................................

Figure 1.7 General Structure of Tetracyclines .......................................................

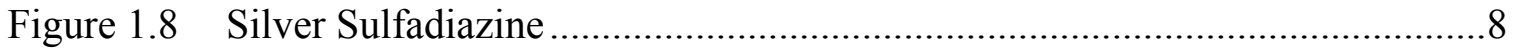

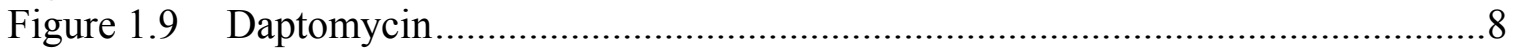

Figure 1.10 Tetramic Acid Ring Structure ................................................................10

Figure 1.11 Naturally Occurring Antimicrobial Tetramic Acids .................................10

Figure 1.12 Lacey-Dieckmann Condensation Mechanism .........................................13

Figure 1.13 Synthetic Pathways to 3-Acyl Tetramic Acids .......................................14

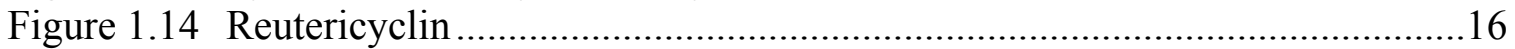

Figure 1.15. Synthetic Routes to Reutericyclin..........................................................17

Figure 2.1 Synthesis of Tetramic Acids and Derivatives .........................................19

Figure 2.2 Internal and External Tautomers of Tetramic Acids..................................21

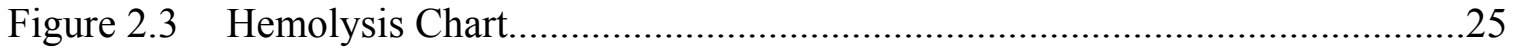




\section{List of Abbreviations}

$\triangle \mathrm{pH}$

Difference in $\mathrm{pH}$

ATP Adenosine triphosphate

Boc tert-Butyl carboxylate

CA-MRSA .Community-acquired methicillin-resistant Staphylococcus aureus

E. coli Escherichia coli

ee Enantiomeric excess

EF-G Elongation Factor $\mathrm{G}$

ESI Electrospray ionization

$\mathrm{Et}_{3} \mathrm{~N}$ Triethylamine

HPLC $\mathrm{MeOH}$ High-performance liquid chromatography

MIC High-performance liquid chromatography
.

MOA High-performance liquid chromatography

MRSA

MS

$\mathrm{OD}_{540}$ Methicillin-resistant Staphylococcus aureus pKa. Mass spectrometry

SAR Optical density at $540 \mathrm{~nm}$ Room temperature

S. aureus .Structure-activity relationship

S. pyogenes Staphylococcus aureus $\mathrm{t}-\mathrm{BuOH}$ Streptococcus pyogenes TFA tert-Butanol THF Trifluoroacetic acid Tetrahydrofuran 


\section{Chapter 1. Introduction}

There is an urgent need for antibacterial agents with distinct modes of action due to increased prevalence of bacteria resistant to current clinically used antibiotics. The need for novel antibiotics is well demonstrated by the emergence of strains of multiple-drug resistant bacteria, such as methicillin-resistant Staphylococcus aureus (MRSA). S. aureus is a frequent cause of life-threatening diseases, such as pneumonia, endocarditis, and a condition known as necrotizing fasciitis, an infection of the fascia that can spread quickly throughout the body and frequently necessitate amputations of affected limbs. These bacteria are also the most common cause of infections of the skin, such as scalded skin syndrome and impetigo, which can worsen and lead to infections of deeper tissue, such as cellulitis or erysipelas. These bacteria are normally commensal residents of skin, but can cause infection upon entering breaks (typically open wounds, although hair follicles can sometimes be a route of entry.) In addition, these bacteria are sometimes a cause of infectious keratitis (inflammation of the cornea), which can lead to scarring and loss of eyesight. In the clinic, topical antibiotics, when used as prophylactics, can prevent serious $S$. aureus infection in high-risk post-surgical patients, and are useful as treatments for some types of skin infections such as impetigo.

Since its emergence in the 1960s, MRSA has primarily been a major cause of hospitalacquired infection. In recent decades, however, community-acquired MRSA (CAMRSA) strains have emerged and are now a significant cause of skin and soft tissue infections in several community settings across the United States. These strains are different from hospital-acquired strains, which tend to be less virulent, and they are increasingly prevalent in both community and hospital settings. In view of the etiology of disease by CA-MRSA and the growing concern stemming in both community and hospital settings, the need for strategies to counteract this organism is even more pressing.

Recently, the synthesis of a series of novel tetramic acid (2,4-pyrrolidinedione) compounds that possess effective antibacterial activity has been reported. ${ }^{1,2}$ Although these agents are effective in vitro, they exhibit toxicity to mammalian cells, with a pronounced tendency toward lysis of red blood cells. ${ }^{1,2}$ This attribute would be expected to cause undesirable or harmful side effects, ranging from skin irritation to systemic toxicity, if the tetramic acids were used clinically. These agents possess lipophilic functional groups, which are thought to be the root of the hemolytic activity due to eukaryotic cell membrane penetration and disruption. The consequent focus of this synthetic project is to improve the safety profile of this class of drugs by introducing functional groups with reduced lipophilicity, with the aim of minimizing their hemolytic activity but retaining their antimicrobial activity. Furthermore, a reduction in the cytotoxicity of tetramic acids could lead to novel molecules with greater potential for systemic administration. This chapter will begin by examining the properties and mechanisms of action of current clinical antibiotics used to treat skin and skin structure infections, then cover the mode of action of known tetramic acid antibiotics and, finally, methods for their synthesis. 


\section{Current Antibiotics Used to Treat Skin and Soft Tissue Infections}

As shown in Table 1.1, a number of antibiotics are currently used for the treatment of skin and soft tissue infections; their methods of action (MOAs), however, are different from those of tetramic acids. This section will cover a sample of the variety of compounds currently in clinical use for such infections.

\section{Inhibitors of Bacterial Cell Wall Synthesis}

\section{Penicillins}

The development of $\beta$-lactam antibiotics was initiated in 1928 when Fleming noted the antimicrobial properties of the a substance produced by spores of Penicillium chrysogenum mold contaminating a culture of Staphylococcus aureus. ${ }^{3}$ Isolation of the active component, Penicillin F (Figure 1.1), was accomplished in the 1940 by Florey, Chain, and Heatley, and its clinical efficacy demonstrated shortly thereafter. Penicillin F did not experience widespread clinical use, but a number of variations on it were soon isolated, and some of these alternative penicillins are still in use today, most notably benzylpenicillin, also termed penicillin G (Figure 1.1). Subsequent work on this molecule permitted numerous semi-synthetic analogues with improved antimicrobial spectrum and durability against bacterial defenses to be produced. The activity of the $\beta$ lactam antibiotics lies in prevention of bacterial cell wall biosynthesis. The cell wall of both Gram-positive and Gram-negative bacteria contains a cross-linked peptidoglycan layer that provides support against lysis of the cells' contents via osmosis. The peptidoglycan layer consists of chains of alternating glucose and $\mathrm{N}$ - acetylmuramic acid connected by $O$-glycosidic bonds. These chains are cross-linked via amino acids connected to the muramic acid subunits to provide greater strength; typically, in $S$. aureus, five amino acids are connected to the muramic acid, and to these amino acids are

Table 1.1. Methods of Action of Existing Topical Antibiotics.

\begin{tabular}{ll}
\hline \multicolumn{1}{c}{ Drug Type } & \multicolumn{1}{c}{ Point and Method of Action } \\
\hline $\begin{array}{l}\text { Penicillins } \\
\text { Cephalosporins }\end{array}$ & Cell wall assembly (inhibition of peptidoglycan cross-linking) \\
Bacitracin & Cell wall assembly (inhibition of peptidoglycan cross-linking) \\
Cell wall assembly (inhibition of dephosphorylation) & Protein synthesis (inhibition of isoleucyl t-RNA \\
aminoacylation) & \\
Fusidic acid & Protein synthesis (inhibition of elongation factor G) \\
Tetracyclines & Protein synthesis (inhibition of tRNA binding to ribosomal site) \\
Silver sulfadiazine & DNA synthesis (inhibition of folate biosynthesis) \\
Daptomycin & Cell membrane permeabilization (induction of $\mathrm{K}^{+}$ion efflux) \\
\hline
\end{tabular}

Source: Modified with permission from Gelmetti, C. Local antibiotics in dermatology. Dermatologic Therapy, 2008, 21, 187-195. ${ }^{4}$ 


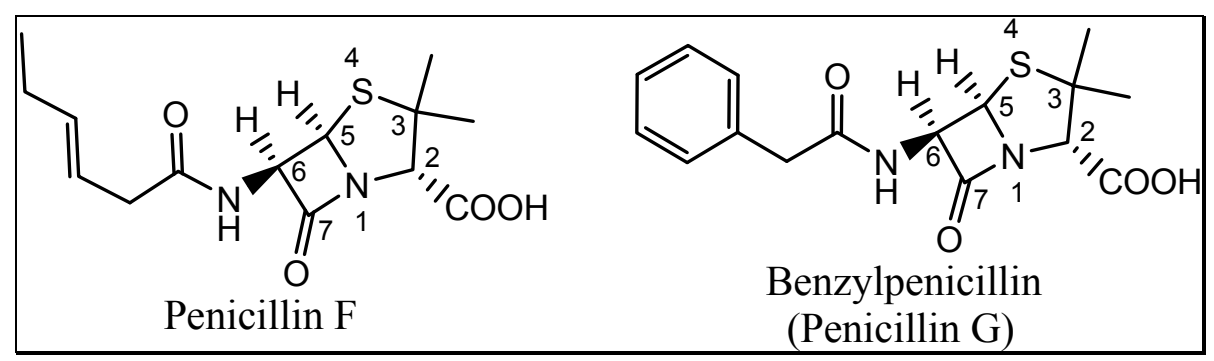

Figure 1.1. Earliest Penicillins.

attached a pentaglycine chain that connects the amino acids between peptidoglycan chains. In the cross-linking, or transpeptidation step, a preassembled, peptidoglycan chain (losing an alanine in the process) is attacked by a terminal glycine to connect the chains. This process is catalyzed by the enzyme transpeptidase. The $\beta$-lactams prevent cell wall cross-linking by mimicking the D-Ala-D-Ala substituent present in the crosslinking step; consequently, the $\beta$-lactam is attacked by a penicillin-binding-protein's Ser$\mathrm{OH}$, leading to an irreversible attachment of the penicillin molecule to the protein. With the penicillin-binding proteins rendered inactive, peptidoglycan cross-linking cannot occur, and so bacterial cell walls weaken, leading to eventual lysis and cell death.

The earliest penicillins' C7-N1 amide bond was highly acid labile, necessitating parenteral administration to avoid the strongly acidic environment of the stomach; however, $\alpha$-amino substitution to the amide with electron-withdrawing groups, as in ampicillin (Figure 1.2) helped to overcome this limitation. A major impediment to the efficacy of the first $\beta$-lactams was the bacterial development of $\beta$-lactamases, enzymes that hydrolyze the amide bond of the lactam ring, rendering it ineffective. Semi-synthetic analogues of penicillin with resistance to lactamase-induced cleavage have been developed; a key component of the structure-activity relationship (SAR) of these resistant penicillins is the substitution of bulky groups at the $\alpha$-amino position (as in methicillin, Figure 1.2) to inhibit the action of $\beta$-lactamases without significantly reducing affinity for penicillin-binding proteins.

\section{Cephalosporins}

Cephalosporins (Figure 1.3) are structurally and functionally highly similar to penicillins, the main difference being an eight-membered rather than seven-membered bicyclic main ring, which confers greater stability and consequent lower reactivity. This reduced reactivity is typically compensated for by the presence of a leaving group $(R)$ at the ring carbon $\beta$ to the carboxyl (COOR) group. Many cephalosporins have been generated because of their inherent resistance to $\beta$-lactamases and increased spectrum of activity. 


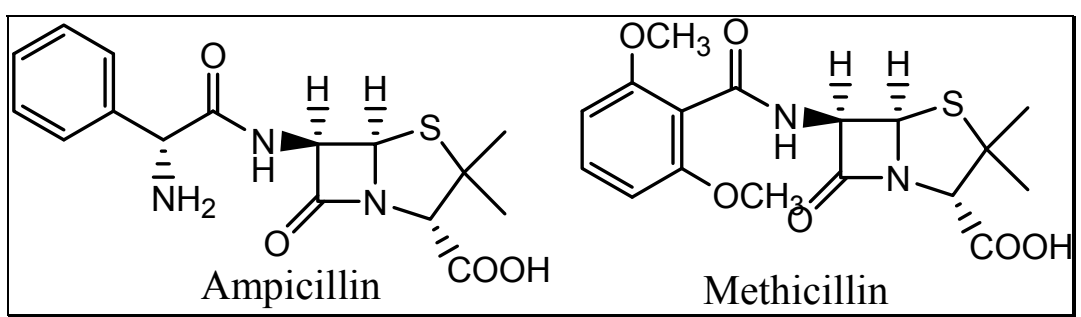

Figure 1.2. Modified Penicillins.

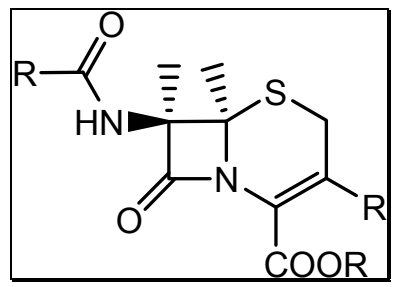

Figure 1.3. General Structure of Cephalosporins. 


\section{Peptide-Based Cell Wall Inhibitors}

An inhibitor of cell wall biosynthesis commonly in use as an antibacterial ointment is bacitracin, a mixture of cyclic peptides synthesized by strains of Bacillus licheniformis. ${ }^{5,6}$ The main component of the mixture is a cyclic oligopeptide designated Bacitracin A (Figure 1.4). Bacitracin functions by inhibiting the dephosphorylation of the $\mathrm{C}_{55^{-}}$ isoprenyl pyrophosphate, which, in its dephosphorylated state, carries assembled peptidoglycan units (with their attached amino acids) to an endogenous acceptor outside the cell membrane. ${ }^{5,6}$ With the dephosphorylation step inhibited, the cell wall cannot be assembled. Bacitracin is systemically toxic in humans, however, and thus is limited to topical application.

\section{Protein Biosynthesis Inhibitors}

Several classes of topical antibiotics prevent the synthesis of proteins via action on ribosomal components. These include mupirocin, fusidic acid, and tetracyclines.

\section{Mupirocin}

Mupirocin (Figure 1.5), a mixture of bacterially synthesized fatty acids, is employed in the treatment of skin infections caused by $S$. aureus. Mupirocin is used solely as a topical antibiotic since it undergoes in vivo hydrolysis, which prevents it from being effective systemically. It functions by inhibiting bacterial isoleucyl t-RNA synthetase. When this enzyme is blocked, isoleucine cannot be connected to a molecule of t-RNA. At low concentrations, mupirocin is bacteriostatic, as its starvation of the cellular supply of isoleucine arrests protein synthesis and triggers repression of RNA synthesis. ${ }^{7}$ At higher concentrations, the mixture is bactericidal due to its blockade of protein synthesis and multiple other effects on the cell, including cell wall damage.

\section{Fusidic Acid}

A compound isolated from the fungus Fusidium coccineum, ${ }^{4}$ fusidic acid (Figure 1.6) inhibits protein biosynthesis by forming a complex with elongation factor G (EF-G) that prevents it from dissociating from the ribosome. ${ }^{8}$ EF-G catalyzes the transfer of tRNA from the ribosomal A site (to which an aminoacylated tRNA binds during protein synthesis) to the $\mathrm{P}$ site (where the growing peptide chain is located prior to linkage with the A site amino acid), but must dissociate from the ribosome to leave space for the next aminoacylated tRNA to enter the A site. Halting this cycle does not kill bacteria, but does halt their reproduction; fusidic acid's action is specific to prokaryotic ribosomes. Its main disadvantage is rapid emergence of resistance compared with other types of antibiotics; it is also effective solely against Gram-positive bacteria. 


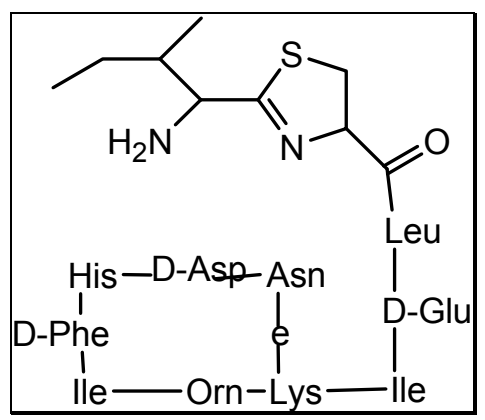

Figure 1.4. Bacitracin.

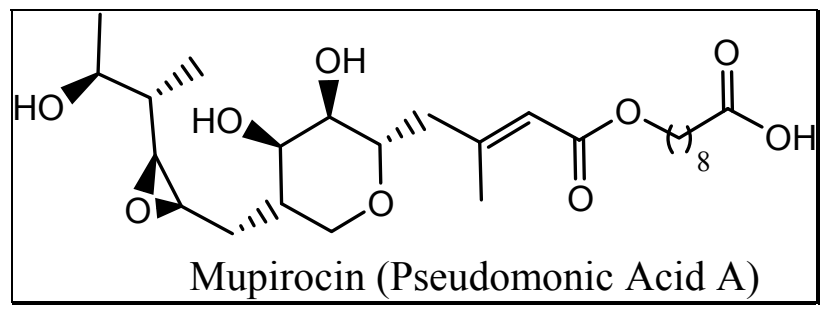

Figure 1.5. Mupirocin.

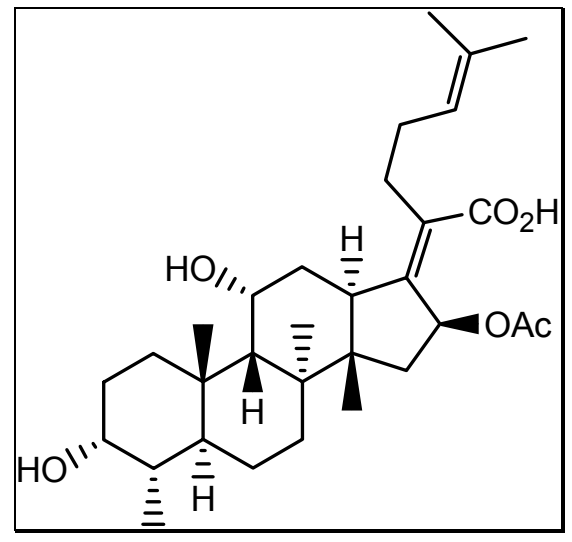

Figure 1.6. Fusidic Acid. 


\section{Tetracyclines}

Tetracyclines (Figure 1.7) are a semi-synthetic class of drugs often prescribed as a treatment for acne vulgaris. Their mode of action is binding to the bacterial $30 \mathrm{~S}$ ribosomal subunit and inhibition of aminoacyl-tRNA binding to the A site. Tetracyclines are clinically bacteriostatic, in part because their interaction with the ribosome is reversible. ${ }^{9}$ Microbial resistance to the tetracycline class, which occurs via efflux pumps, ribosomal protection proteins (which interact with the ribosome and render it immune to tetracycline-induced inactivation), and enzymatic inactivation of the drug, is now widespread. ${ }^{9}$ This situation has significantly reduced their clinical utility.

\section{DNA Biosynthesis Inhibitors}

The first class of antimicrobials was a variety of fully synthetic drugs known as the sulfonamides. This class of drugs acts by halting the biosynthesis of tetrahydrofolate, an essential factor in the synthesis of the DNA bases guanine and adenine. Specifically, they compete with the natural substrate (para-aminobenzoic acid) for the active site of dihydropteroate synthase. Sulfonamides act selectively because bacteria synthesize tetrahydrofolate de novo, whereas humans synthesize it from dietary folic acid. This inhibition of DNA synthesis does not destroy bacteria, but prevents reproduction, allowing the host's immune system to eliminate the infection. As such, sulfonamides are classified as bacteriostatic (i.e. inhibitors of bacterial reproduction) rather than bactericidal. The most relevant preparation, commonly used to treat burns, is silver sulfadiazine salt (Figure 1.8).

\section{Membrane-Destabilizing Agents}

Daptomycin (Figure 1.9), a cyclic lipopeptide derived from Streptomyces roseosporus, possesses an unusual antibacterial mode of action in that it depolarizes bacterial membranes by causing the $\mathrm{Ca}^{2+}$-dependent gradual release of $\mathrm{K}^{+}$ions, but without forming pores. ${ }^{10}$ This activity severely and quickly reduces the viability of a bacterial culture to nearly zero, presumably because the depolarization of the membrane causes rapid release of necessary intracellular ions. ${ }^{10}$ The development of this molecule is significant, as it demonstrates a novel mode of action on the bacterial membrane. As it

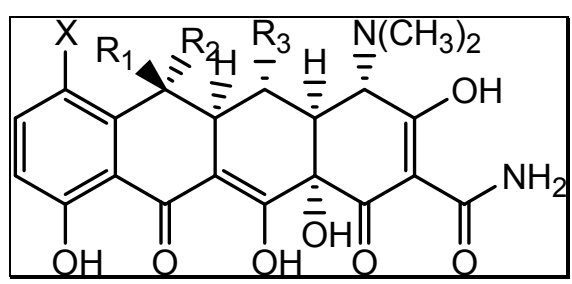

Figure 1.7. General Structure of Tetracyclines. 


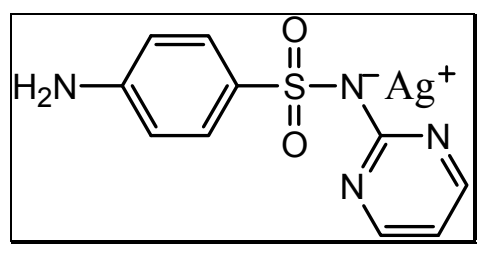

Figure 1.8. Silver Sulfadiazine.

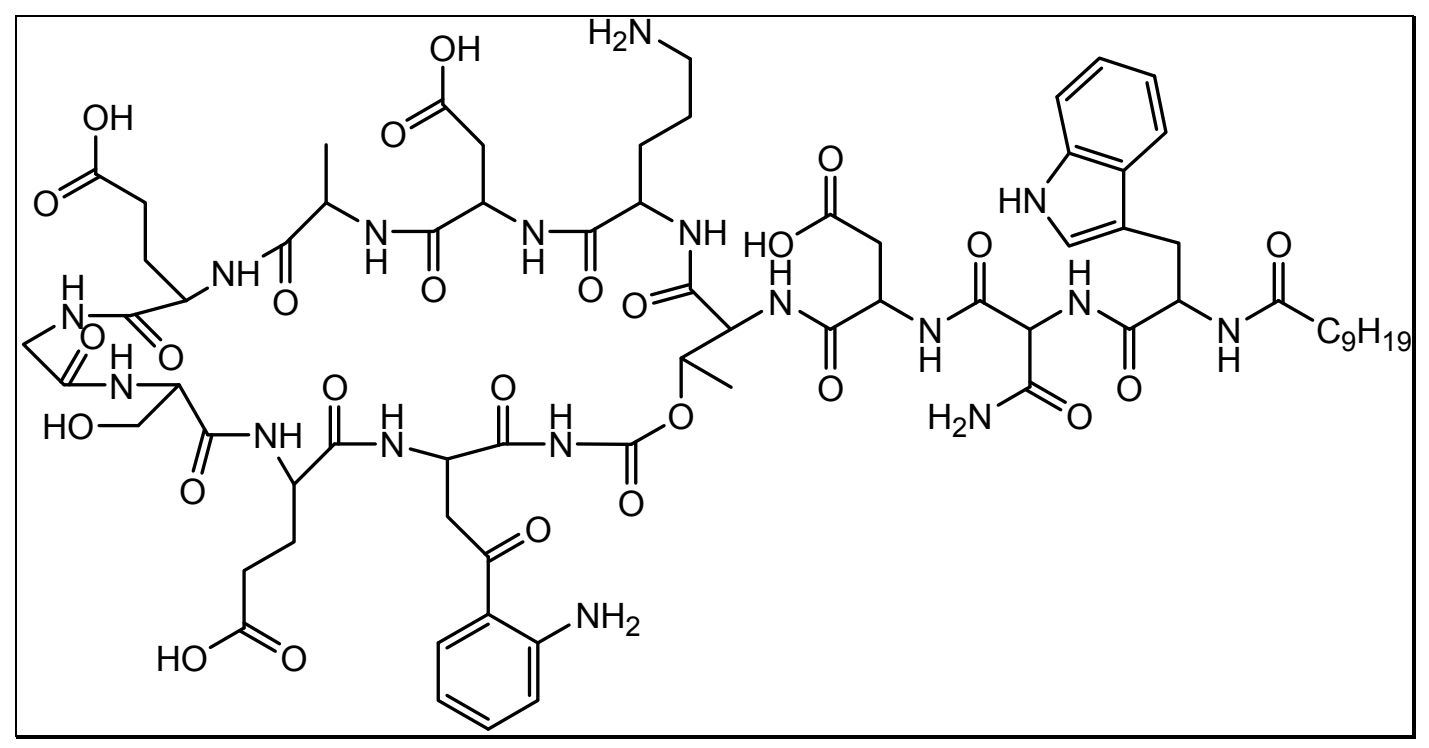

Figure 1.9. Daptomycin. 
selectively permeabilizes bacterial as opposed to mammalian membranes, it provides a precedent for the pursuit and development of tetramic acids - which act in a similar fashion — as clinically relevant drugs.

\section{Naturally-Occurring Tetramic Acids}

Tetramic acids, or pyrrolidine-2,4-diones, are an important class of naturally occurring molecules synthesized by numerous organisms. Members of this naturally occurring class exhibit various significant biological activities, including antimicrobial activity. A number of methods for their synthesis are present in the available literature. The pursuit of compounds containing tetramic acid groups with therapeutic properties has been undertaken for several decades, although comparatively few studies have been devoted toward their potential as anti-infective agents.

A number of tetramic-acid containing molecules with demonstrated antimicrobial activity have been isolated from a variety of natural sources. However, the types of substituents on the common pyrrolidine ring (Figure 1.10) vary widely, as might be expected. Wangun and Hertweck ${ }^{11}$ have reported the isolation of a small set of fungal isolates with 5-tyrosyl and 3-(dimethylnonyl)acetyl substitution; activity against Mycobacterium vaccae was observed. Equisetin (Figure 1.11), first isolated by Burmeister et al., ${ }^{12}$ was first shown to be effective against several species of gram-positive bacteria, but not against the majority of tested Gram-negative bacteria. The compound trichosetin (Figure 1.11), isolated by Marfori et al., ${ }^{13}$ is an N-desmethyl homolog of equisetin containing a 5(ethanol) and 3-[1,6-dimethyl-2-propenyl 1,2,4- $\alpha, 5,6,7,8,8-\alpha$ octahydronaphthyl acyl] substituent and, notably, having activity against $S$. aureus and Bacillus subtilis at nanogram concentrations. The actinomycete derivatives Bu-2313A and B (Figure 1.11) have demonstrable activity against the common skin pathogens Streptococcus pyogenes (S. pyogenes) and Propionibacterium acnes, ${ }^{14}$ particularly the former.

Streptolydigin (Figure 1.11), a bacterial isolate, has been shown to inhibit RNA polymerase in a fashion similar to the rifamycin compounds currently in clinical use ${ }^{15}$ as a consequence, it indirectly inhibits protein biosynthesis. Examination of its method of action has revealed that although it acts faster at inhibiting RNA polymerization and pyrophosphate exchange with ribonucleotide triphospates, both its pyrophosphate exchange sensitivity and inhibitory capacity are weaker by a factor of approximately one hundred. ${ }^{15}$ The structurally similar compound tirandamycin ${ }^{16}$ (Figure 1.11) also inhibits Escherichia coli-derived RNA polymerase, but is not selective in that it also inhibits mammalian RNA polymerase ${ }^{16}$ and mammalian mitochondrial respiration. ${ }^{17}$ Both compounds demonstrate activity against several Gram-positive but not Gram-negative bacteria, with bacteria of the Bacteroides genus being the only Gram-negative exception. ${ }^{18}$

The melophlins, a sizable group of 3-acyl tetramic acids, (Figure 1.11), are (chiefly) derived from the marine sponge Melophlus sarassinorum; at least nineteen such compounds have been isolated. ${ }^{19-21}$ Their structures are similar in that they are all $\mathrm{N}$ - 


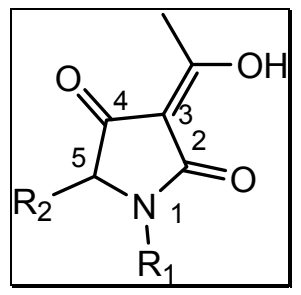

Figure 1.10. Tetramic Acid Ring Structure.

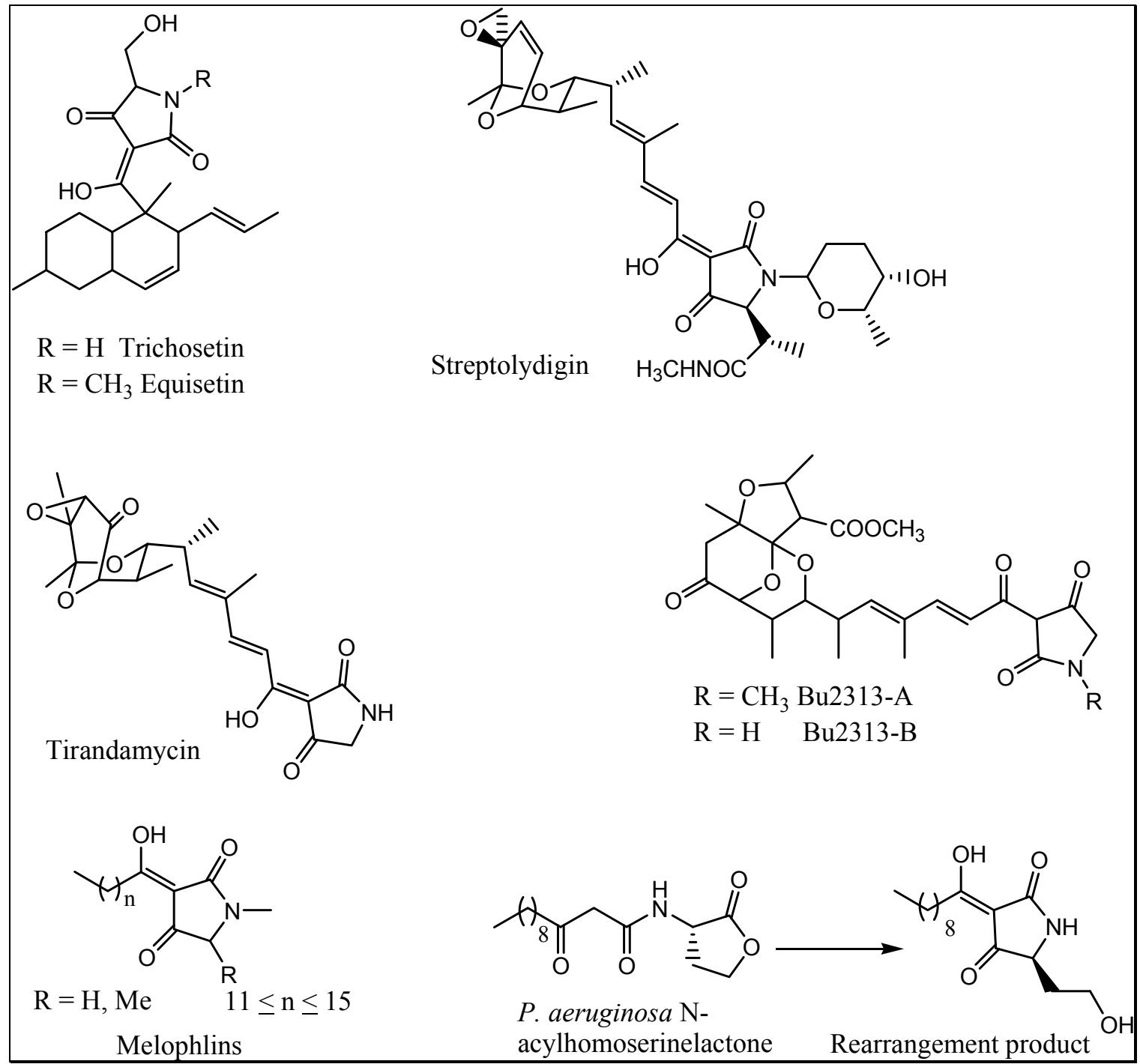

Figure 1.11. Naturally Occurring Antimicrobial Tetramic Acids. 
methylated, and possess either an $\mathrm{H}$ or $\mathrm{CH}_{3}$ substitution at the $\mathrm{C}-5$ position; their key differences are the length of the main alkyl chain $\left(\mathrm{C}_{12}\right.$ to $\mathrm{C}_{16}$, including carbonyl) of the 3 -acyl substituent and the position of the chain's branching. Some of the melophlins have biological properties, including cytotoxic (translating to potential anticancer drugs) and antibacterial activity; the latter category includes melophlins $\mathrm{C}$ and $\mathrm{G}$, which both have demonstrable activity against Bacillus subtilis and $S$. aureus. ${ }^{22}$

A potential biological function of compounds with the tetramic acid moiety was proposed by Kaufmann et al., ${ }^{23}$ in which an autoinducer $N$-acylhomoserine lactone produced by the Gram-negative bacterium Pseudomonas aeruginosa unexpectedly underwent aqueous solvent-promoted rearrangement to a tetramic acid moiety. Both the precursor molecule and the tetramic acid product (Figure 1.11) exhibited inhibitory activity against nine different species of Gram-positive bacteria, including several strains of the Gram-positive bacterium Bacillus cereus. However, no notable activity against Gram-negative species E. coli or Salmonella typhimurium was observed. It was proposed that the MOA of this product is similar to that of reutericyclin (see below); namely, it functions as an ionophore and dissipates the bacterial transmembrane difference of $\mathrm{pH}$, leading to cell lysis. $^{23,24}$ It also exhibits a high inhibitory constant due to ready penetration of the cell membrane via its high lipophilicity. ${ }^{23,24}$

It should be noted that that these natural products were, albeit with exceptions, found to be considerably more active against Gram-positive bacteria than Gram-negative bacteria. The most likely explanation is that tetramic acid compounds are unlikely to penetrate fully the outer lipopolysaccharide layer of Gram-negative bacteria in order to reach the bacterial inner membrane.

\section{Tetramic Acid Structure-Activity Relationship Investigations}

Numerous syntheses of products containing tetramic acid moieties have been undertaken, several of which have been directed toward the synthesis of natural products; these syntheses may have a use in initiating optimization of the structure-activity relationships exhibited by natural products. Tetramic acids not found in nature also comprise a portion of syntheses undertaken thus far, although comparatively few studies have focused on the SAR of substitutions. A number of natural products, including those mentioned above, possess a diene chain connected to the 3-acyl group. A study by Rosen et al. ${ }^{25}$ investigated the effects of varying terminal aromatic groups on this 3-dienoyl substituent in an effort to mimic the RNA polymerase inhibitory activity of streptolydigin and tirandamycin A; these synthesized compounds either lacked C-5 or N-1 substitution or were methylated at these positions. The noted SAR was that $\mathrm{N}$-methylation provided only a minor reduction in minimum inhibitory concentration, whereas C-5 methylation dramatically weakened activity. An acyclic terminal functional group had far weaker activity than an aromatic ring, as well. Toda et al. ${ }^{14}$ tested the effects of substitution at the tetramic acid's C-5 position on the aforementioned Bu2313-A and B, and found that functionalities that were electron-withdrawing or larger than ethyl tended to have reduced 
activity against Propionibacterium acnes and Streptococcus pyogenes, particularly the latter.

Attention should be drawn to the fact that the active compounds noted above lack extensive substitution on the $\mathrm{N}-1$ position; rather, all of them possess an $\mathrm{N}-\mathrm{H}$ or $\mathrm{N}-\mathrm{CH}_{3}$ functionality. They also typically possess 3 -acyl substitution, frequently with either unsaturated alkyl chains or a double bond at the carbon $\beta$ to the carbonyl carbon. This fact leaves the question open as to the potential, if any, of variations on substitutions at the N-1 position. Yendapally et al. ${ }^{1}$ tested the effectiveness of 3-acyl tetramic acids without substitution on the 3-acetyl functional group, and with varied $\mathrm{N}$ - and 5substitutions. A trend found in the activity of this series of compounds was that lipophilic functional groups (long alkyl chains or aromatic and cyclic hydrocarbons) at the N-position conferred the greatest antibacterial activity, although the leucine, isoleucine, valine, and phenylalanine-based lipophilic side chains at the 5-position conferred few differences in potency relative to each other. ${ }^{1}$

\section{Synthetic Methods for Tetramic Acids}

Biosynthesis of tetramic acids is most often stereospecific, with the following general assembly procedure: The $\mathrm{N}-1, \mathrm{C}-5$, and $\mathrm{C}-4$ positions on the ring are most commonly derived from an amino acid (with the 5-position substituted with the amino acid side chain), while the C-2 and C-3 positions are provided from acetate, which, in the case of 3 -polyenoyl tetramic acids, is connected to preformed polyketides. ${ }^{26}$

Assembly of the 2,4-pyrrolidine diketone ring itself and introduction of varied substituents at the 1-, 3-, and 5-positions are the main challenges faced in synthesis of analogues. Toward this end, a number of synthetic methods have been devised. Although numerous methods of introducing 3-substituents are available, a great many bioactive tetramic acids possess 3-acyl functional groups, and it is these that are most relevant to the current project. As such, the following discussion of synthetic methods will be limited to those that produce the 3 -acyl ring component.

The most common method of synthesis of the 3-acyl substituted ring is a version of the Dieckmann condensation (Figure 1.12), involving base-promoted intramolecular $C$ acylation of $N$-acetoacetyl $\alpha$-amino esters. ${ }^{27}$ (Competitive reactions involving other acidic protons in the molecule would not be expected due to steric hindrance.) This condensation typically takes place in protic solvent with a strong base, such as sodium methoxide or potassium tert-butoxide (Scheme W; Figure 1.13). ${ }^{28}$ The chief problem with this method, however, is that racemization at C-5 is common, as the C-5 hydrogens are acidic (a condition stemming from their proximity to the electron-withdrawing heteroatom and C-4 carbonyl) and can be readily removed under the strongly basic conditions needed for the condensation. A few methods exist for generation of the acetoacetyl $\alpha$-amino esters, including - if the desired final tetramic acid is to be unsubstituted at C-5 - condensation of an alkylaminoacetonitrile with diketene; the molecule can be converted to a lithium enolate and cyclized (Scheme X; Figure 1.13). ${ }^{29}$ 


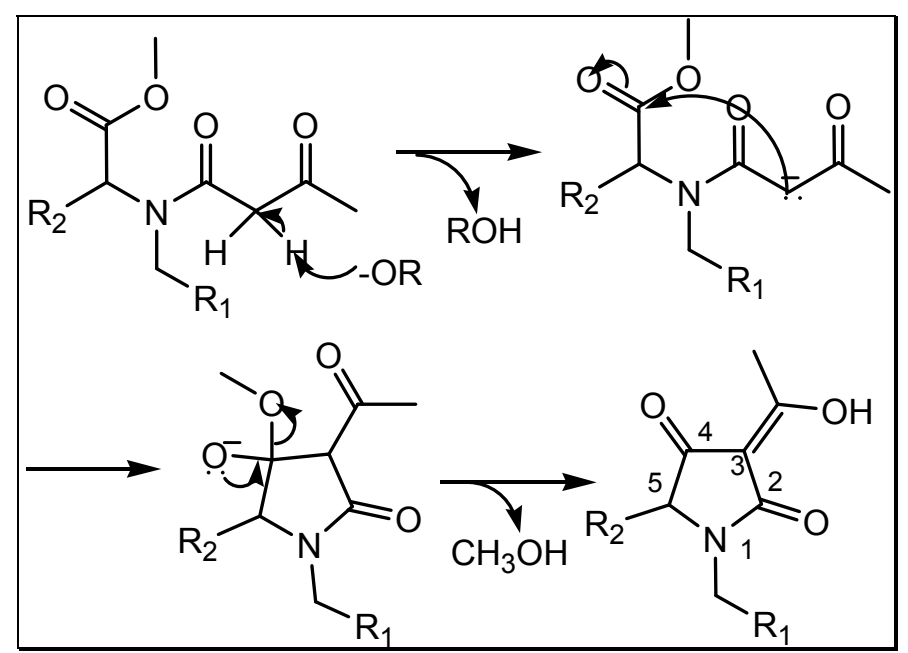

Figure 1.12. Lacey-Dieckmann Condensation Mechanism. 


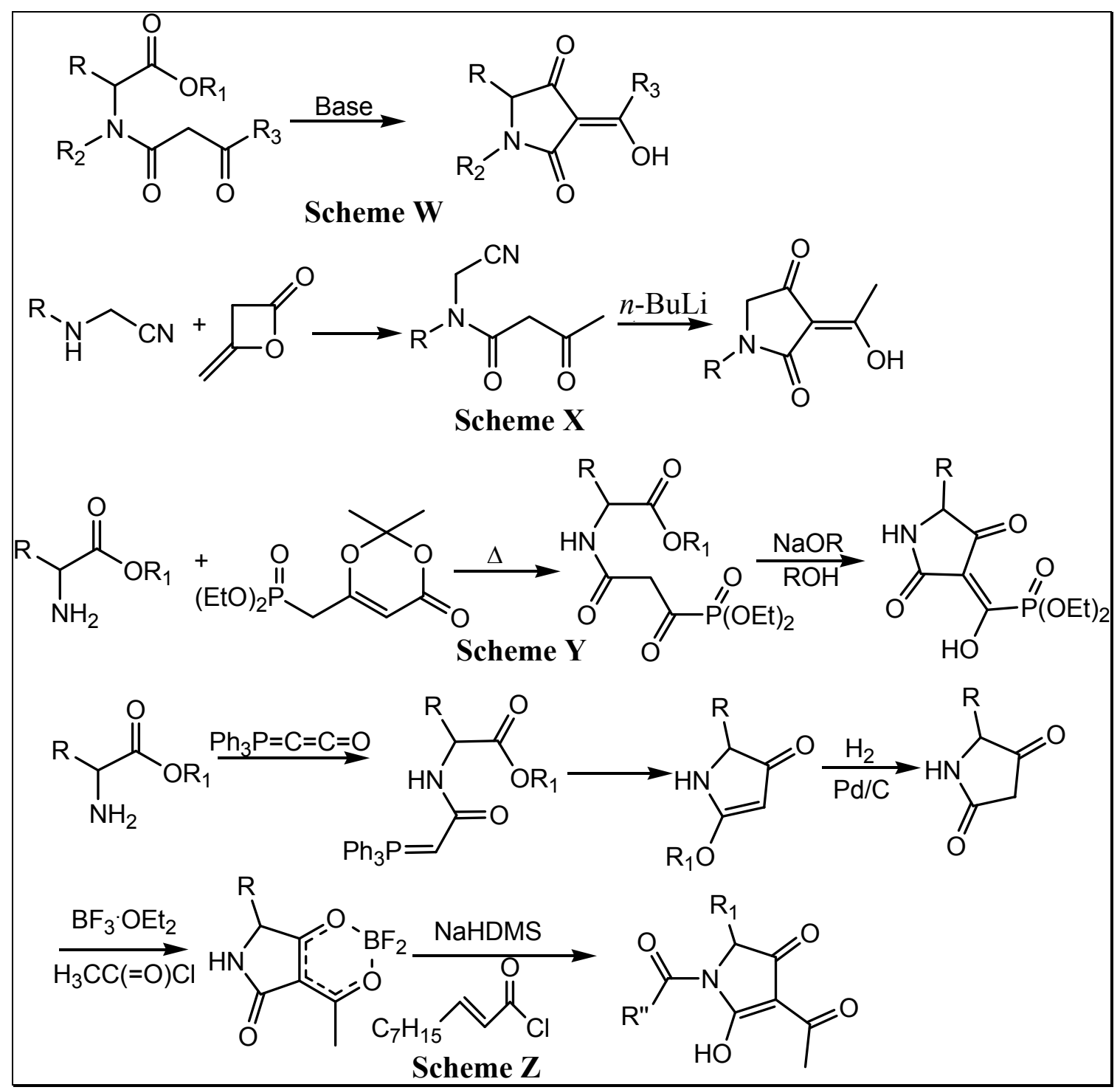

Figure 1.13. Synthetic Pathways to 3-Acyl Tetramic Acids. 
The $N$-acetoacetyl ester intermediates can also be generated by reaction of $\alpha$-amino esters with a diethylphosphonate acetone diketene adduct, followed by Dieckmann condensation (Scheme Y; Figure 1.13). An advantage of this method is that it allows Wadsworth-Emmons olefination to be performed subsequent to ring formation, if the final molecule is to be a 3-dienoyl compound. ${ }^{30}$ A reported synthesis using an acetoacetyl ester attached to a solid support noted near-quantitative yield, but made no mention of stereoselectivity. ${ }^{31}$ Alternative protocols for ring formation require subsequent 3-acylation. One such method, employed by Jouin et al., ${ }^{32}$ employs Knoevenagel condensation of $\alpha$-amino acids with Meldrum's acid, followed by heating to cause intramolecular amidation with elimination of acetone and carbon dioxide. Lewis acids, such as boron trifluoride or titanium tetrachloride, can couple acyl chlorides to the ring.

An additional method of stereospecific ring formation uses a domino reaction sequence wherein (triphenylphosporanylidene)ketene $\left(\mathrm{Ph}_{3} \mathrm{P}=\mathrm{C}=\mathrm{C}=\mathrm{O}\right)$ is added across the terminal amine of a chosen amino acid precursor to form active agents that rapidly undergo intraWittig reaction to form the tetramic acid ring (Scheme Z; Figure 1.13).$^{26,33}$ This method is largely free of C-5 epimerization and can be performed under $\mathrm{pH}$-neutral conditions. The pathway toward ring formation without inclusion of the 3-acyl substituted tetramic acids involves synthesis of the core ring, followed by 3 -acylation. The known methods for acylation, however, each suffer limitations on applicability in the presence of various functional groups. ${ }^{26}$ The 4-O acylation of the ring with the desired carboxylic acid, followed by a shift to the $\mathrm{C}-3$ position, is accomplished by addition of the carboxylic acid along with dicyclohexylcarbodiimide (DCC) and 4,4-dimethylaminopyridine (DMAP), as initially reported by Hori et al. ${ }^{34}$ Reaction of the completed N-methyl, 3-unsubstituted tetramic acid ring with thallous ethoxide, followed by acetyl fluoride, was reported to yield 3-acetyl product; however, analogous reaction with acyl fluorides with longer chains tended to give 4-O-acylated product instead. ${ }^{29}$

\section{Reutericyclin Properties and Synthetic Approaches}

Reutericyclin (Figure 1.14) is a natural product of significant interest, as it exhibits antimicrobial activity in a fashion somewhat different from known antibiotics. The compound, isolated from Lactobacillus reuteri, is found in sourdough bacterial colonies, and has demonstrable bactericidal activity against other microbial residents. In a fashion similar to organic acids used in food preservation, ${ }^{24}$ reutericyclin acts as a proton ionophore and selectively dissipates bacterial cell membrane $\Delta \mathrm{pH}$, leading to reduced chemopotential energy (necessary for ATP biosynthesis and active transport of molecules) and eventual cell death. (The pKa of reutericyclin is in the range of 2 to $3 .^{24}$ ) It is active against Gram-positive bacteria, but not Gram-negative species; the production of reutericyclin is thought to give the bacterium a competitive advantage against rival species. ${ }^{35}$ The molecule's amphiphilic nature is thought to allow it to penetrate the cell lipid layer while acting as a depolarizing agent via its tetramic acid ring. As L. reuteri is a frequent resident of human and animal intestinal microflora, as well as food preparations, ${ }^{36}$ it represents a possible lead compound for safe antimicrobial agents. 


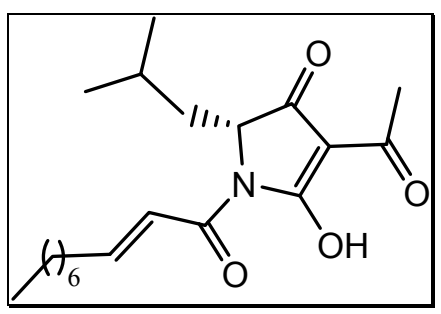

Figure 1.14. Reutericyclin.

Several synthetic routes to reutericyclin have been devised, with varying degrees of success; these routes have been mentioned above and are outlined in Figure 1.15. The first synthesis, as noted by Böhme et al, ${ }^{37}$ employed the aforementioned method of cyclization of $\mathrm{N}$-acylated amino acid with Knoevenagel condensation with Meldrum's acid, followed by heat-promoted cyclization ${ }^{32}$ and 3-acylation catalyzed by titanium tetrachloride; the final step caused racemization at the C-5 position (Scheme X, Figure 1.15). A more successful synthetic route employed $N$-acetoacetylation with $N$ (hydroxysuccinimidyl)acetoacetate followed by Dieckmann condensation with sodium ethoxide, then $N$-acylation promoted by butyllithium; the final compound was produced in $80 \%$ enantiomeric excess (ee) (Scheme Y, Figure 1.15). ${ }^{37}$ The most effective chiral synthesis employed the domino Wittig sequence described above, ${ }^{26}$ employing Disoleucine benzyl ester and $\mathrm{Ph}_{3}=\mathrm{C}=\mathrm{C}=\mathrm{O}$ to cyclize the ring, followed by boron trifluoride-promoted acylation and ultimate N-deprotonation/acylation, to produce reutericyclin in $95 \%$ ee (Scheme Z, Figure 1.15). ${ }^{26}$

Having explored the mechanism of action of currently available antimicrobial agents and surveyed the potential of existing tetramic acids, I will, in the next chapter, detail how knowledge of the structure-activity relationship of tetramic acids, and methods for synthesizing them, may be used to achieve the goal of developing active compounds with an improved safety profile. 


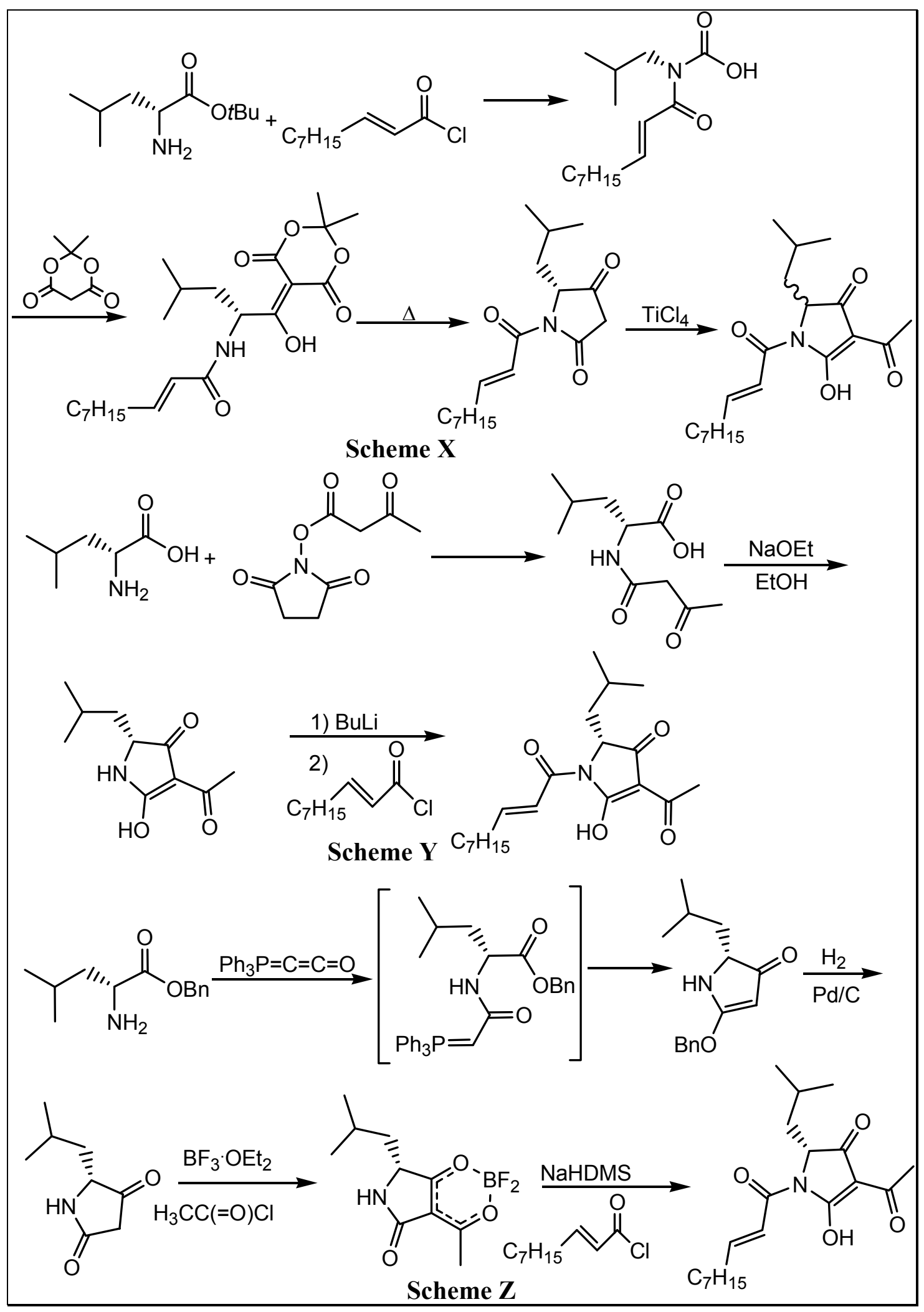

Figure 1.15. Synthetic Routes to Reutericyclin. 


\title{
Chapter 2. Synthesis, Characterization, and Evaluation of Substituted Tetramic Acid Compounds as Antibacterial Agents
}

\author{
Introduction
}

The current series of compounds was based on a previously synthesized series of antibacterial tetramic acids by Yendapally et al. ${ }^{1,2}$ in which a set of 3-acetyl tetramic acids resembling the natural antibiotic reutericyclin was made. These compounds possessed varying amino acid-derived 5-substitutions (phenylalanine, leucine, isoleucine, and valine). Several N-substituents, which were more stable to enzymatic degradation than the $\mathrm{N}$-acyl substituent of reutericyclin, were incorporated into these compounds as well. The tested compounds with the most potent antibacterial activity were, in general, those with highly lipophilic N-substituents; these substituents were theorized to be effective at penetrating bacterial cell membranes. Although these compounds exhibited potent antibacterial activity in vitro, concerns arose about their cytotoxicity, particularly a hemolytic effect on human red blood cells, which was thought to stem from a combination of the membrane-penetrating capacity imparted by the highly lipophilic N1and C5-substituents and the acidic nature of the tetramic acid ring. ${ }^{2}$ In light of these facts, in this study, different 5 -substituents generated from polar and basic amino acids were employed in an effort to balance the negative charge of the acidic tetramic acid ring and confer greater amphiphilicity, thus altering interaction with mammalian membranes. The working hypothesis is that reduction of eukaryotic membrane damage could reduce clinical side effects such as skin irritation (if used topically) or hemolytic anemia (if administered intravenously). It is worth noting that many non-lytic membrane-active antibiotics are amphiphilic, perhaps most notably daptomycin. A novel series of 5substituted tetramic acids was synthesized, and the compounds were tested for their antimicrobial efficacy and hemolytic activity.

Results and Discussion

\section{Synthetic Evaluation}

The synthetic route utilized for this project (Figure 2.1), adapted from the protocol of Yendapally, ${ }^{2}$ was chosen because of its established effectiveness in synthesizing 3-acyl tetramic acids with nonpolar functional groups at the ring's $\mathrm{N}$ and $\mathrm{C}-5$ positions. ${ }^{1,2}$ Based on the antimicrobial activity of these prior compounds, the N-substituted functional groups expected to confer the strongest activity were 4-phenylbenzyl (a), myrtenyl (b), and decyl (c). 4-Ethylbenzyl (d) and 4-methoxybenzyl (e) (Figure 2.1) were also used to test the effect of varying the para-substituent on the benzyl group, relative to 4-phenylbenzyl. After completion of the synthesis of these compounds, preliminary antimicrobial and hemolytic studies were performed. Based on these findings, the myrtenyl group, which resulted in minimal hemolysis compared with activity against 


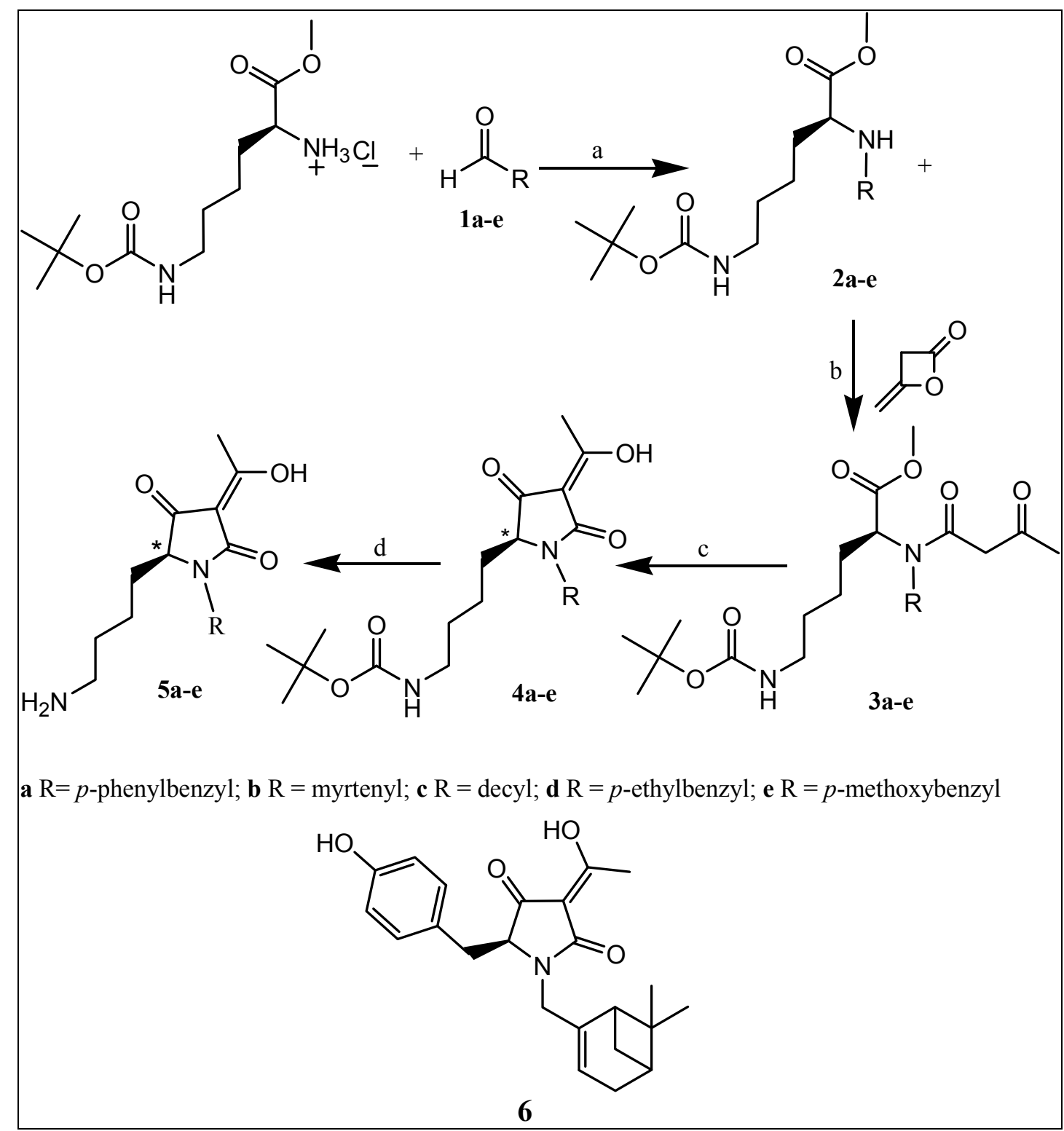

Figure 2.1. Synthesis of Tetramic Acids and Derivatives. Reagents and conditions: (a) (i) THF, $\mathrm{Et}_{3} \mathrm{~N}, \mathrm{MgSO}_{4}, 5 \mathrm{~h}$, rt (ii) $\mathrm{MeOH}, \mathrm{NaBH}_{4}, 30$ min, rt (b) $\mathrm{CH}_{2} \mathrm{Cl}_{2}, \mathrm{Et}_{3} \mathrm{~N}, 6 \mathrm{~h}$, reflux (c) t-BuOH, $\mathrm{Na}^{+} t-\mathrm{BuO}^{-}$or $\mathrm{K}^{+} t-\mathrm{BuO}^{-}, 1 \mathrm{~h}, 40^{\circ} \mathrm{C}$ (d) THF, TFA, $1 \mathrm{~h}$, rt.

* Indicates racemizations may have occurred during synthesis. 
S. aureus, was selected to be paired with the tyrosine side chain as a different polar Nsubstituent to produce compound 6 (Figure 2.1), via the same synthetic scheme. In the initial synthetic step for all the compounds, amino acid (tyrosine or N-Boc lysine) methyl ester hydrochloride was $\mathrm{N}$-substituted by reductive amination with aldehydes 1a-e and $\mathrm{Et}_{3} \mathrm{~N}$ as basic catalyst in anhydrous $\mathrm{THF}$, using anhydrous $\mathrm{MgSO}_{4}$ to maintain anhydrous conditions. The resulting imine intermediates were reduced with $\mathrm{NaBH}_{4}$ in methanol to form secondary amines, in total yields between $29.6-82.9 \%$. The secondary amine products $2 \mathbf{a}-\mathbf{f}$ were acylated with diketene in $\mathrm{CH}_{2} \mathrm{Cl}_{2}$ at reflux, employing $\mathrm{Et}_{3} \mathrm{~N}$ in catalytic amount, to form $N$-acetoacetyl- $\alpha$-amino esters in yields between $36.2-79.0 \%$. To form the tetramic acid rings, the $N$-acetoacetyl- $\alpha$-amino esters 3a-f were cyclized via Lacey-Dieckman condensation ${ }^{27}$ with sodium or potassium $t$-butoxide in $t$-butanol (these bases were chosen for their reduced tendency to cause isomerization) ${ }^{28}$ to give nearly quantitative yields. The rather high observed yields for these compounds probably derive from the presence of a remnant of the reactant, as the reaction mixtures were subjected to aqueous/organic extraction but not chromatography. These tetramic acids 4 a-f were tested for antimicrobial activity. For further testing, the Boc group was, as per the procedure of Rakesh et al., ${ }^{38}$ removed from the N-Boc lysine-derived tetramic acids with TFA in THF to form primary amines 5a-e as their TFA salts. The TFA cleavage step proved to be the most difficult, with incomplete reaction being the norm and frequently requiring a second run of the reaction before MS testing demonstrated the disappearance of the starting material.

The main divergence of structure, compared with the prior series, was the functional group at the C-5 position. Greater difficulty was expected in the use of polar amino acid starting materials, as they had potential to interfere with each of the three main steps $(\mathrm{N}-$ alkylation, $\mathrm{N}$-acylation, and ring closure), and to make purification difficult, as highly polar functional groups tend to adsorb strongly onto silica-based chromatography columns. These difficulties were circumvented by the use of N-Boc-protected lysine; however, cleavage of the protecting group with trifluoroacetic acid proved difficult, necessitating comparatively long reaction times and repeated evaporation to remove the material, and forming salts rather than the desirable free base. The final products, whether protected or deprotected, were also highly polar and resistant to elution on thinlayer silica plates, and so silica-based flash chromatographic purification was not attempted. An inherent difficulty in assigning NMR peaks to the products was also encountered due to the presence of tautomers in the $\mathrm{N}$-acylacetoamine intermediates 3a-e (Figure 2.1) and in the ultimate tetramic acid products. There are a total of nine possible tautomers of 3-acyl tetramic acids, ${ }^{39}$ but only four, shown in Figure 2.2, are present in detectable concentrations. They consist of internal and external pairs which interconvert too rapidly to be detected on the NMR time scale, although the rate of conversion between internal and external pairs is sufficient to determine their ratio of concentration if their NMR signals are distinguishable. ${ }^{39}$ Intramolecular hydrogen bonding, as shown in Figure 2.2, would be expected to improve the stability of the enol tautomers $\mathbf{A}$ and $\mathbf{C}$ of the 3-acyl group. For these reasons, mass spectrometry was the most useful technique to determine the presence or absence of the final product. A similar use was made of reversed-phase HPLC, which was invaluable in determining the purity of the ultimate reaction mixtures, as the tetramic acid ring acts as a UV chromophore. 


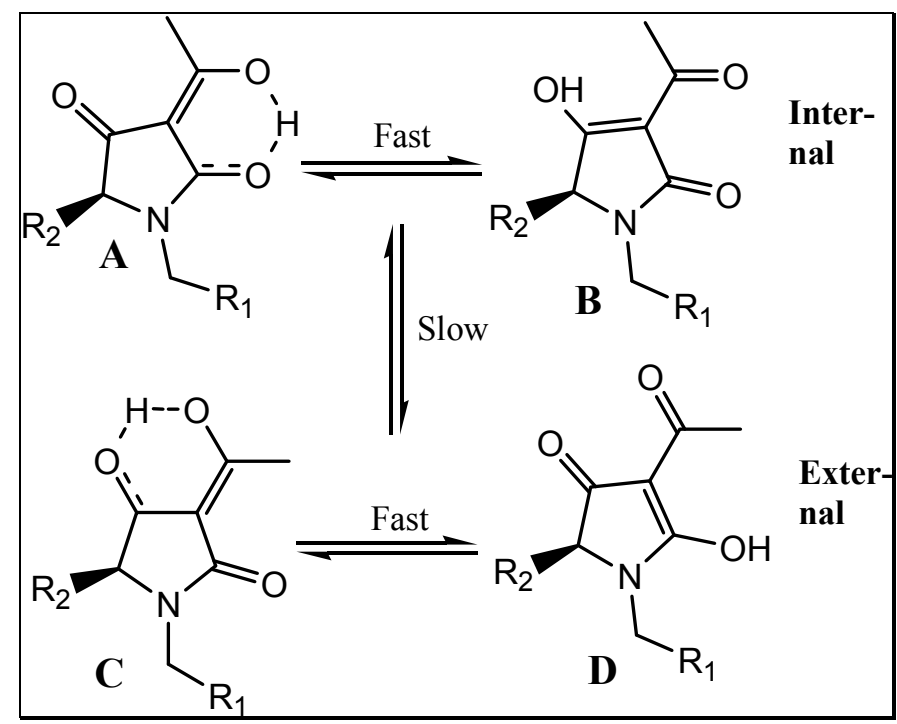

Figure 2.2. Internal and External Tautomers of Tetramic Acids.

\section{Biological Evaluation}

Ultimately, eleven tetramic acid compounds were synthesized and tested against a small panel of clinically relevant bacteria: Staphylococcus aureus (methicillin-susceptible), Enterococcus faecalis, and Bacillus anthracis. No Gram-negative bacteria were tested, as tetramic acids are generally inactive against them. This is most likely due to a lack of penetration of the outer membrane of Gram-negative bacteria, although, a few exeptions to this trend have been noted; ${ }^{1,2,23}$ consequently, Gram-negative bacteria would not be expected to serve as reliable negative controls. Tables 2.1 and 2.2 illustrate the structureactivity relationship of the current series, with compounds 867 and 1138 included as a comparison of the compounds with the strongest activity from the prior series. ${ }^{1,2}$

Among the compounds with the Boc protecting group, the predicted activity trends were nearly the opposite of the outcome. The biphenyl and myrtenyl functional groups of $\mathbf{4 a}$ and $\mathbf{4 b}$ conferred essentially no activity against $S$. aureus or E. faecalis, although $\mathbf{4 a}$ had moderate activity against $B$. anthracis. The other compounds possessed greater activity against all the bacteria tested, although the N-decyl group (4c), surprisingly, averaged no more potency than the aromatic compounds (4d-e). These findings are in contrast to the findings of the earlier study, ${ }^{1,2}$ in which the myrtenyl and decyl N-substituents offered among the greatest potency.

The primary amine compounds (Table 2.2) had greater activity than the Boc-protected compounds in the majority of cases, although it should be noted that the deprotected compounds typically had lower purity due to some remaining starting materials. As with the parent series, ${ }^{1,2}$ unlike with the Boc-protected class, the most effective compounds possessed a bicyclic ring derived from myrtenyl (5b) or a long-chain alkyl group at N-1 (5c). Although the presence of a primary amine imparted generally greater activity 
Table 2.1: Structures and Activities of Tetramic Acids.

\begin{tabular}{|c|c|c|c|c|c|c|c|c|}
\hline \multirow{2}{*}{ General Structure } & \multirow{2}{*}{ No. } & \multirow{2}{*}{$\mathrm{R}_{1}$} & \multirow{2}{*}{$\mathrm{R}_{2}$} & \multicolumn{3}{|c|}{$\mathrm{MIC}(\mu \mathrm{g} / \mathrm{mL})$} & \multirow{2}{*}{$\begin{array}{c}\text { Mol. } \\
\text { Wt. }\end{array}$} & \multirow{2}{*}{$C \log P$} \\
\hline & & & & MSSA & $\mathrm{EF}$ & BA & & \\
\hline & $867 \dagger$ & & & 0.4 & 1.6 & 0.8 & 239.31 & 6.50 \\
\hline & $1138 \dagger$ & & & 1.6 & 1.6 & 0.8 & 331.45 & 5.42 \\
\hline & $4 a$ & & & 200 & $>200$ & 25 & 478.58 & 5.06 \\
\hline & $4 b$ & & & $>200$ & $>200$ & $>200$ & 446.58 & 4.89 \\
\hline & $4 c$ & & & 50 & 25 & 6.25 & 452.63 & 6.49 \\
\hline & $4 d$ & & & 25 & 50 & 12.5 & 430.54 & 4.20 \\
\hline & $4 e$ & & & 12.5 & 12.5 & 50 & 432.51 & 3.09 \\
\hline
\end{tabular}

MIC: Minimum inhibitory concentration. MSSA: Methicillin-susceptible Staphylococcus aureus 8325; EF: Enterococcus faecalis ATCC 33186; BA: Bacillus anthracis Sterne 34F2. Mol. Wt.: Molecular weight. CLogP was calculated using ChemDraw Ultra, Version 7.0 software by Cambridge Soft.

†Source: Yendapally, R.; Hurdle, J. G.; Carson, E. I.; Lee, R. B.; Lee, R. E., N-Substituted 3-acetyltetramic acid derivatives as antibacterial agents. J. Med. Chem. 2008, 51, (5), 1487-1491. ${ }^{1}$ 
Table 2.2. Structures and Activities of Tetramic Acids.

\begin{tabular}{|c|c|c|c|c|c|c|c|c|}
\hline \multirow{2}{*}{ General Structure } & \multirow{2}{*}{ No. } & \multirow{2}{*}{$\mathrm{R}_{1}$} & \multirow{2}{*}{$\mathrm{R}_{2}$} & \multicolumn{3}{|c|}{$\mathrm{MIC}(\mu \mathrm{g} / \mathrm{mL})$} & \multirow{2}{*}{$\begin{array}{l}\text { Mol. } \\
\text { Wt. }\end{array}$} & \multirow{2}{*}{$\mathrm{CLog} \mathrm{P}$} \\
\hline & & & & MSSA & $\mathrm{EF}$ & BA & & \\
\hline & $867 \dagger$ & & & 0.4 & 1.6 & 0.8 & 239.31 & 6.50 \\
\hline & $1138 \dagger$ & & & 1.6 & 1.6 & 0.8 & 331.45 & 5.42 \\
\hline $\mathrm{R}_{1}$ & $5 a$ & & & 100 & 200 & 12.5 & 378.46 & 3.31 \\
\hline & $5 \mathbf{b}$ & & & 25 & 25 & 25 & 346.46 & 3.66 \\
\hline & $5 c$ & & & 25 & 25 & 25 & 352.51 & 4.75 \\
\hline & 5d & & & $>200$ & 200 & 12.5 & 330.42 & 2.46 \\
\hline & $5 e$ & & & 200 & 25 & 200 & 332.39 & 1.35 \\
\hline & 6 & & & 25 & 12.5 & 25 & 381.46 & 4.71 \\
\hline
\end{tabular}

MIC: Minimum inhibitory concentration. MSSA: Methicillin-susceptible Staphylococcus aureus 8325; EF: Enterococcus faecalis ATCC 33186; BA: Bacillus anthracis Sterne 34F2. Mol. Wt.: Molecular weight. CLogP was calculated using ChemDraw Ultra, Version 7.0 software by Cambridge Soft.

†Source: Yendapally, R.; Hurdle, J. G.; Carson, E. I.; Lee, R. B.; Lee, R. E., N-Substituted 3-acetyltetramic acid derivatives as antibacterial agents. J. Med. Chem. 2008, 51, (5), 1487-1491. ${ }^{1}$ 
relative to the Boc-protected compounds, the effect was less pronounced for the compounds with $\mathrm{N}-1$ benzylic substitution (5a, 5d-e). With respect to the bacterial species, the compounds as a whole tended to be most effective against Bacillus anthracis, but the activity trends were generally similar for each of the three bacterial species tested.

Hemolytic trends were far clearer than antibacterial activity trends (Figure 2.3); at the highest concentration of compound used $(100 \mu \mathrm{g} / \mathrm{mL})$, the primary amino lysine-derived compounds were, as hypothesized, less hemolytic than the Boc-protected compounds (except in the case of the 4-ethylbenzyl pair 4d and 5d). At lower concentrations, the hemolytic activities were considerably more similar for the protected and deprotected pairs. A similar statement can be made for compound 6; namely, that despite its lack of a basic functional group that has potential for carrying a positive charge, the presence of a hydrogen bond donor may be sufficient for reducing erythrocyte lysis without apparent loss of antimicrobial activity.

A comparison between the current series and the earlier series illustrates some significant changes. The antimicrobial activities of the present compounds, which possess polar functionalities at C-5, are considerably lower than the earlier compounds 867 and $1138^{1,2}$ possessing an isobutyl substituent at C-5 (Table 2.1). However, a comparison between the present and previous compounds reveals a dramatic reduction in hemolysis at 100 $\mu \mathrm{g} / \mathrm{mL}$ (Figure 2.3). The reduced antimicrobial activities of these molecules may be explainable in terms of reduced affinity for the membrane by the lipophilic N-functional groups. The free-amino compounds should be, hypothetically, amphipathic due to the acidic diketone paired with basic primary amine. In all instances, the lipophilic Nsubstituent is likely to partition into the Gram-positive bacterial plasma membrane, whether the tetramic acid has an overall neutral or negative charge. If the ring is amphipathic, however, the N-substituent's position in the membrane becomes less energetically stable due to positive interactions with the membrane's prevalent internal negative charges, and the tetramic acid is less able to maintain the position it requires for its depolarization of the membrane.

It may appear that reduction of hemolytic activity is incompatible with improvement of antibacterial activity. However, the mechanism of action on red blood cells membranes is thought to be different from that on bacterial in that bacteria rely on membrane potential difference for energy, whereas eukaryotic cells rely on mitochondria; therefore, ionophores would be expected to have weaker effects on eukaryotic cells. Also, it has been suggested that hemolysis stems from membrane solubilization rather than ionophoric activity. As such, there is potential for designing tetramic acids with selective activity, which could translate to clinically safe antimicrobials.

\section{Conclusions}

The chosen synthetic route led to the successful synthesis of several tetramic acids with a polar functional group at the $\mathrm{C}-5$ position. The hemolytic activity of the compounds synthesized was, as hypothesized, lowered due to the inclusion of a polar substituent at 


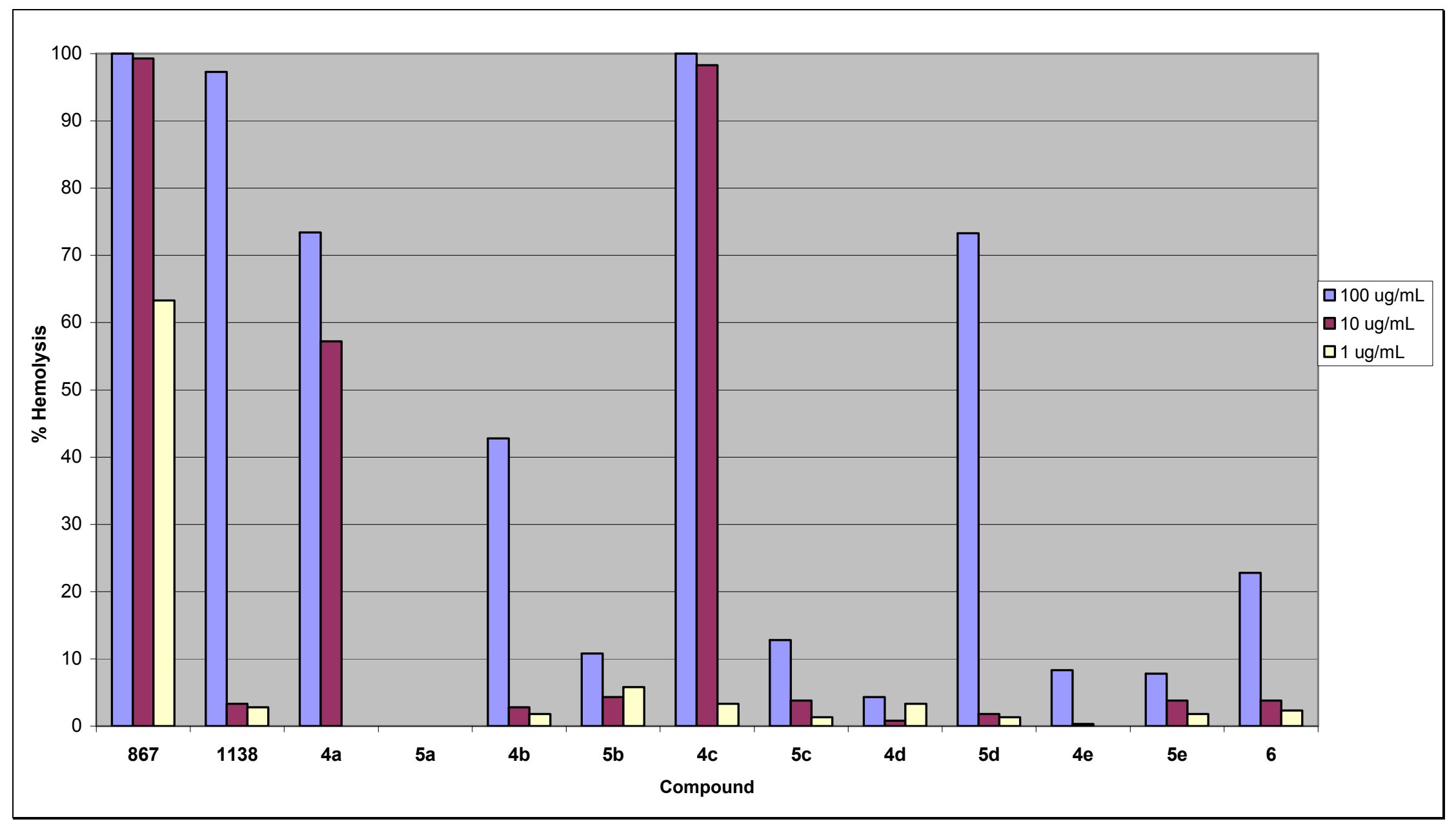

Figure 2.3. Hemolysis Chart. \% Hemolysis: Measured as optical density at $540 \mathrm{~nm}$ of supernatant of suspended erythrocyte samples to which a quantity of drug sufficient to provide the necessary concentration had been added and incubated. Negative controls were non-hemolytic antibiotics ampicillin and doxycycline; positive control was Triton-X (induced 100\% hemolysis). 
C-5. Their antimicrobial activity, however, was weakened, potentially for the same reason. Possible ways of increasing the antimicrobial potency may include alkylation of the free amino compounds to improve lipophilicity and penetration into bacterial membranes. Also, as compound $\mathbf{6}$ exhibited antimicrobial activity comparable to several of the free amino compounds, and fairly low hemolytic activity, the synthesis of other compounds with similar polar but nonbasic substitution may merit further investigation. Future studies will be required to expand the tetramic acid series, maintaining low hemolytic activity while increasing antimicrobial activity.

\section{Experimental Section}

\section{Chemistry}

\section{General Synthetic Scheme}

Amino acid (N-Boc L-lysine or L-tyrosine) methyl ester hydrochloride was N-substituted by reductive amination with aldehydes $\mathbf{1 a}$-e and $\mathrm{Et}_{3} \mathrm{~N}$ in anhydrous THF in the presence of $\mathrm{MgSO}_{4}$ to maintain anhydrous conditions. The resulting imine intermediates were reduced with $\mathrm{NaBH}_{4}$ in methanol. The resulting secondary amines $\mathbf{2 a - f}$ were acylated with diketene in $\mathrm{CH}_{2} \mathrm{Cl}_{2}$ at reflux, employing $\mathrm{Et}_{3} \mathrm{~N}$ in catalytic amount. To form the tetramic acid rings, the acetoacetyl amides 3a-f were cyclized via Lacey-Dieckman condensation ${ }^{26}$ with sodium or potassium $t$-butoxide in $t$-butanol (these bases were chosen for their reduced tendency to cause isomerization). These tetramic acids $\mathbf{4 a - f}$ were tested for antimicrobial activity. For further testing, the Boc group was removed from the N-Boc lysine-derived tetramic acids with TFA in THF to form primary amines 5a-e as their TFA salts. The TFA cleavage step proved to be the most difficult, with incomplete reaction being the norm and frequently necessitating a second trial before MS testing demonstrated the disappearance of the starting material.

\section{Experimental Methods}

${ }^{1} \mathrm{H}$ NMR was performed on either a Varian Unity INOVA $500 \mathrm{MHz}$ spectrometer or a Bruker-ARX $300 \mathrm{MHz}$ spectrometer. Mass spectra were recorded on a Bruker-Esquire LC-MS using ESI. Flash chromatography was performed on a Biotage Horizon HPFC system, employing Biotage FLASH $25+\mathrm{M}$ cartridges. Yields quoted are unoptimized. HPLC1, HPLC2, HPLC3, and HPLC4 methods were followed using a Phenomenex platinum C-18 reverse phase column $(100 \AA, 50 \times 4.6 \mathrm{~mm})$ at ambient temperature, and a flow rate of $1.0 \mathrm{~mL} \mathrm{~min}{ }^{-1}$. HPLC1: Gradient: solvent $\mathrm{A}(0.1 \%$ TFA in water $)$ and solvent B (acetonitrile): 0-2.00 min. 100\% A, 2.00-7.00 min. 0-100\% B (linear gradient), 7.008.00 min. $100 \%$ B, $8.00-9.90$ min. $100-0 \% \mathrm{~B}$ (linear gradient), 9.90-10.00 min. 0\%B, UV detection at $254 \mathrm{~nm}$. HPLC2: Gradient: solvent A (0.1\% TFA in water) and solvent B (acetonitrile): $0-1.00 \mathrm{~min} 0-80 \% \mathrm{~B}$ (linear gradient), $1.00-7.5 \mathrm{~min} 80 \%-100 \% \mathrm{~B}$ (linear gradient), 7.5-8.00 min 100\% B, 8.00-9.00 min. 100-0\% B (linear gradient), 9.00-10.00 
min. 100\% A, UV detection at $254 \mathrm{~nm}$. HPLC3: Gradient: solvent A $(0.1 \%$ TFA in water) and solvent B (acetonitrile): $0-2.00 \mathrm{~min} 35 \% \mathrm{~B}, 2.00-7.00 \mathrm{~min} 35-100 \% \mathrm{~B}$ (linear gradient), $7.00-8.00 \mathrm{~min} 100 \% \mathrm{~B}, 8.00-9.00 \mathrm{~min} 100-35 \% \mathrm{~B}$ (linear gradient), 9.00-10.00 $\min 35 \% \mathrm{~B}$, UV detection at $254 \mathrm{~nm}$. HPLC4: Gradient: solvent A (0.1\% TFA in water $)$ and solvent B (acetonitrile): 0-2.00 min 100\%A, 2.00-17.00 min 0-100\%B (linear gradient), $17.00-18.00 \mathrm{~min} 100 \% \mathrm{~B}, 18.00-19.90 \mathrm{~min} 100-0 \% \mathrm{~B}$ (linear gradient), 19.90$20.00 \mathrm{~min} 0 \% \mathrm{~B}$, UV detection at $254 \mathrm{~nm}$.

Solvents were purchased from Sigma-Aldrich and Fisher and used without further purification. All reagents were provided by Sigma-Aldrich, except for L-tyrosine methyl ester, which was provided by EMD Biosciences.

General procedure for preparation of secondary amines (2a-d.) The L-amino acid methyl ester hydrochloride salt ( 1 equiv) was dissolved in anhydrous THF, and to it were added aldehyde (2 equiv), $\mathrm{Et}_{3} \mathrm{~N}$ ( 1 equiv), and $\mathrm{MgSO}_{4}$ (1.7 equiv). The mixture was allowed to stir at room temperature under argon for a minimum of $6 \mathrm{~h}$, then filtered and evaporated in vacuo to yield the crude imine. The crude imine was directly dissolved in methanol, and to it was slowly added $\mathrm{NaBH}_{4}$ (2 equiv). The reaction mixture was quenched with excess $1 \mathrm{~N} \mathrm{NaOH}$ and extracted with ethyl acetate, then dried over $\mathrm{Na}_{2} \mathrm{SO}_{4}$ and concentrated in vacuo. The crude secondary amine was then purified by flash chromatography via a petroleum ether/ethyl acetate gradient.

6-tert-Butoxycarbonylamino-2-(4-phenyl-benzylamino)-hexanoic acid methyl ester (2a). To a solution of L-lysine methyl ester hydrochloride $(0.5 \mathrm{~g}, 1.68 \mathrm{mmol})$ in anhydrous THF $(10 \mathrm{~mL})$ were added biphenyl-4-carboxaldehyde $(0.614 \mathrm{~g}, 3.37 \mathrm{mmol})$, $\mathrm{Et}_{3} \mathrm{~N}(235 \mu \mathrm{L}, 1.68 \mathrm{mmol})$, and $\mathrm{MgSO}_{4}(0.345 \mathrm{~g}, 2.86 \mathrm{mmol})$, and left to stir at rt under argon overnight. The reaction mixture was filtered, then concentrated in vacuo to yield the crude imine. The crude imine was then dissolved in methanol, and $\mathrm{NaBH}_{4}(0.127 \mathrm{~g}$, $3.37 \mathrm{mmol}$ ) added to it slowly. The mixture was stirred at $\mathrm{rt}$ for $30 \mathrm{~min}$, then quenched with excess $1 \mathrm{~N} \mathrm{NaOH}$ and extracted with ethyl acetate, then worked up as in the general procedure to yield $0.531 \mathrm{~g}(73.9 \%)$ of $2 \mathrm{a}$ as syrup. ${ }^{1} \mathrm{H} \mathrm{NMR}\left(500 \mathrm{MHz}, \mathrm{CD}_{3} \mathrm{OD}\right): \delta 1.24$ $(1 \mathrm{H}, \mathrm{t}, J=7.25 \mathrm{~Hz}), 1.32-1.41(2 \mathrm{H}, \mathrm{m}), 1.41-1.49(11 \mathrm{H}, \mathrm{m}), 1.62-1.71(2 \mathrm{H}, \mathrm{m}), 2.01(1 \mathrm{H}$, s), $3.02(2 \mathrm{H}, \mathrm{t}, J=6.25 \mathrm{~Hz}), 3.29(1 \mathrm{H}, \mathrm{t}, J=7.75 \mathrm{~Hz}), 3.65(1 \mathrm{H}, \mathrm{d}, J=13.5 \mathrm{~Hz}), 3.71$ $(3 \mathrm{H}, \mathrm{s}) 3.80(1 \mathrm{H}, \mathrm{d}, J=13 \mathrm{~Hz}), 4.10(1 \mathrm{H}, \mathrm{q}, J=7.17 \mathrm{~Hz}) 7.30-7.34(1 \mathrm{H}, \mathrm{t}, J=7.25 \mathrm{~Hz})$, 7.38-7.44 (4H, dd, $J=7.67 \mathrm{~Hz}), 7.55-7.61(4 \mathrm{H}, \mathrm{dd}, J=7.5 \mathrm{~Hz})$. ESI-MS: $449.3(\mathrm{M}+$ $23)$.

6-tert-Butoxycarbonylamino-2-[(6-methyl-bicyclo[3.1.1]hept-2-en-2-ylmethylene)amino]-hexanoic acid methyl ester (2b). To a solution of L-lysine methyl ester hydrochloride $(0.40 \mathrm{~g}, 1.35 \mathrm{mmol})$ in anhydrous THF $(10 \mathrm{~mL})$ were added $(1 R)-(-)$ myrtenal $(410 \mu \mathrm{L}, 2.70 \mathrm{mmol}), \mathrm{Et}_{3} \mathrm{~N}(225 \mu \mathrm{L}, 1.62 \mathrm{mmol})$, and $\mathrm{MgSO}_{4}(0.276 \mathrm{~g}, 2.29$ $\mathrm{mmol})$, and left to stir at $\mathrm{rt}$ under argon for $10.5 \mathrm{~h}$. The reaction mixture was filtered, then concentrated in vacuo to yield the crude imine. The crude imine was dissolved in 10 $\mathrm{mL}$ methanol, then $0.102 \mathrm{~g} \mathrm{NaBH}_{4}(2.70 \mathrm{mmol})$ was added slowly. The mixture was stirred at $\mathrm{rt}$ for $30 \mathrm{~min}$, then worked up as described in the general procedure to yield 0.21 $\mathrm{g}(39.5 \%)$ of $2 \mathbf{b} .{ }^{1} \mathrm{H} \mathrm{NMR}\left(500 \mathrm{MHz}, \mathrm{CDCl}_{3}\right): \delta 0.83(3 \mathrm{H}, \mathrm{s}), 1.14(1 \mathrm{H}, \mathrm{d}, J=9 \mathrm{~Hz})$, 
1.27-1.31 (4.4H, m), 1.34-1.40 (2.37H, m), 1.41-1.52 (11.88H, m), 1.54-1.67 (2.28H, m), 1.67-1.72 (1.14H, s), $2.09(2 \mathrm{H}, \mathrm{d}, J=5 \mathrm{~Hz}), 2.18-2.24(2 \mathrm{H}, \mathrm{q}, J=17.3 \mathrm{~Hz}), 2.34-2.39$ $(1.06 \mathrm{H}, \mathrm{m}), 2.95(1 \mathrm{H}, \mathrm{d}), 3.07-3.11(3 \mathrm{H}, \mathrm{m}), 3.24(1 \mathrm{H}, \mathrm{t}), 3.72(3 \mathrm{H}, \mathrm{s}), 4.66(0.83 \mathrm{H}, \mathrm{s})$, $5.36(1 \mathrm{H}, \mathrm{s})$. ESI-MS: $395.3(\mathrm{M}+1), 417.3(\mathrm{M}+23)$.

6-tert-Butoxycarbonylamino-2-decylamino-hexanoic acid methyl ester (2c). To a solution of L-lysine methyl ester hydrochloride $(0.91 \mathrm{~g}, 3.1 \mathrm{mmol})$ and $\mathrm{MgSO}_{4}(0.50 \mathrm{~g}$, $4.2 \mathrm{mmol})$ in anhydrous THF $(25 \mathrm{~mL})$ were added decanal $(0.38 \mathrm{~mL}, 2.0 \mathrm{mmol})$, and $\mathrm{Et}_{3} \mathrm{~N}(0.59 \mathrm{~mL}, 4.2 \mathrm{mmol})$, and the reaction was left to stir at $\mathrm{rt}$. The reaction mixture was filtered, then concentrated in vacuo to yield the crude imine. The crude imine was then dissolved in methanol, and $\mathrm{NaBH}_{4}(0.153 \mathrm{~g}, 4.04 \mathrm{mmol})$ added to it slowly. The mixture was stirred at $\mathrm{rt}$ for $30 \mathrm{~min}$, quenched with excess $1 \mathrm{~N} \mathrm{NaOH}$ and extracted with ethyl acetate, then worked up as described in the general procedure to yield $0.671 \mathrm{~g}$ (82.9\%) of 2c. ${ }^{1} \mathrm{H} \mathrm{NMR}\left(500 \mathrm{MHz}, \mathrm{CDCl}_{3}\right): 0.88(3 \mathrm{H}, \mathrm{t}, J=6.5 \mathrm{~Hz}), 1.18-1.33$ $(13.94 \mathrm{H}, \mathrm{m}), 1.32-1.40(1.8 \mathrm{H}, \mathrm{m}), 1.38-1.53(11.94 \mathrm{H}, \mathrm{m}), 1.57-1.68(2.17 \mathrm{H}, \mathrm{m}), 2.41-$ $2.48(1 \mathrm{H}, \mathrm{m}), 2.50-2.58(1 \mathrm{H}, \mathrm{m}), 3.04(1.15 \mathrm{H}, \mathrm{s}), 3.05-3.14(1.71 \mathrm{H}, \mathrm{m}), 3.20-3.26(1 \mathrm{H}, \mathrm{t}$, $J=6.25 \mathrm{~Hz}), 3.72(3 \mathrm{H}, \mathrm{s}), 4.87(1 \mathrm{H}, \mathrm{bs})$. ESI-MS: $401.4(\mathrm{M}+1), 423.3(\mathrm{M}+23)$.

\section{6-tert-Butoxycarbonylamino-2-(4-ethyl-benzylamino)-hexanoic acid methyl ester} (2d). To a solution of L-lysine methyl ester hydrochloride $(0.40 \mathrm{~g}, 1.35 \mathrm{mmol})$ in anhydrous THF $(10 \mathrm{~mL})$ were added 4-ethylbenzaldehyde $\left(369 \mu \mathrm{L}, 2.70 \mathrm{mmol}^{2}, \mathrm{Et}_{3} \mathrm{~N}\right.$ $(188 \mu \mathrm{L}, 1.68 \mathrm{mmol})$, and $\mathrm{MgSO}_{4}(0.276 \mathrm{~g}, 2.29 \mathrm{mmol})$, and left to stir at rt under argon for $9 \mathrm{~h}$. The reaction mixture was filtered, then concentrated in vacuo to yield the crude imine. The crude imine was then dissolved in methanol $(10 \mathrm{~mL})$, and $\mathrm{NaBH}_{4}(0.1-2 \mathrm{~g}$, $2.70 \mathrm{mmol}$ ) added to it slowly. The mixture was stirred at $\mathrm{rt}$ for $30 \mathrm{~min}$, then quenched with $7 \mathrm{~mL}$ of $1 \mathrm{~N} \mathrm{NaOH}$ and extracted with $3 \times 10 \mathrm{~mL}$ ethyl acetate, then worked up as described in the general procedure to yield $0.248 \mathrm{~g}(48.6 \%)$ of $2 \mathrm{~d}$ as gel. ${ }^{1} \mathrm{H}$ NMR (500 $\left.\mathrm{MHz}, \mathrm{CD}_{3} \mathrm{OD}\right): \delta 1.28(3 \mathrm{H}, \mathrm{t}), 1.34-1.41(2.41 \mathrm{H}, \mathrm{m}), 1.41-1.56(11.19 \mathrm{H}, \mathrm{m}), 1.67-1.77$ $(2 \mathrm{H}, \mathrm{m}), 2.66-2.71(2 \mathrm{H}, \mathrm{q}), 3.06-3.10(2 \mathrm{H}, \mathrm{t}), 3.31-3.35(1 \mathrm{H}, \mathrm{t}), 3.64-3.67(1 \mathrm{H}, \mathrm{d}), 3.77$ $(3 \mathrm{H}, \mathrm{s}), 3.77-3.81(1 \mathrm{H}, \mathrm{d}), 7.20-7.23(2 \mathrm{H}, \mathrm{d}), 7.28-7.31(2 \mathrm{H}, \mathrm{d})$. ESI-MS: $401.3(\mathrm{M}+$ 23).

6-tert-Butoxycarbonylamino-2-(4-methoxy-benzylamino)-hexanoic acid methyl ester (2e). To a solution of L-lysine methyl ester hydrochloride $(0.40 \mathrm{~g}, 1.35 \mathrm{mmol})$ in anhydrous THF (15 mL) were added $p$-anisidine $(367 \mu \mathrm{L}, 3.02 \mathrm{mmol}), \mathrm{Et}_{3} \mathrm{~N}(188 \mu \mathrm{L}$, $1.35 \mathrm{mmol})$, and $\mathrm{MgSO}_{4}(0.276 \mathrm{~g}, 2.29 \mathrm{mmol})$, and left to stir at rt under argon for $6.25 \mathrm{~h}$. The reaction mixture was filtered, then concentrated in vacuo to yield the crude imine. The crude imine was then dissolved in methanol $(15 \mathrm{~mL})$, and $\mathrm{NaBH}_{4}(0.102 \mathrm{~g}, 2.70$ mmol) added to it slowly. The mixture was stirred at $\mathrm{rt}$ for $30 \mathrm{~min}$, then $0.050 \mathrm{~g}$ additional $\mathrm{NaBH}_{4}$ added slowly, and the mixture stirred for an additional $1 \mathrm{~h}$. The reaction was then quenched with excess $1 \mathrm{~N} \mathrm{NaOH}$. Ethyl acetate was added, then the mixture was evaporated to dryness, then reconstituted with methanol, water, and ethyl acetate. The cloudy precipitate in the aqueous layer was drained off, then more water added, and the precipitate drained off again. Finally, the solution was extracted with ethyl acetate, allowing the precipitate to settle out of the organic layer, and the material worked up as in the general procedure to yield $0.152 \mathrm{~g}(29.8 \%)$ of $2 \mathbf{e}$. ${ }^{1} \mathrm{H}$ NMR (300 
$\left.\mathrm{MHz}, \mathrm{CD}_{3} \mathrm{OD}\right): 1.23-1.53(12.49 \mathrm{H}, \mathrm{m}), 1.59-1.73(1.79 \mathrm{H}, \mathrm{m}), 2.94-3.10(1.72 \mathrm{H}, \mathrm{m})$, $3.26(0.83 \mathrm{H}, \mathrm{t}, J=11.2 \mathrm{~Hz}), 3.52-3.68(1.09 \mathrm{H}, \mathrm{m}), 3.69(0.75 \mathrm{H}, \mathrm{s}), 3.73(2.11 \mathrm{H}, \mathrm{s}), 3.78-$ $3.88(2.90 \mathrm{H}, \mathrm{m}), 6.83-6.99(1.92 \mathrm{H}, \mathrm{m}), 7.16-7.40(2 \mathrm{H}, \mathrm{m})$. ESI-MS: $487.3(\mathrm{M}+23)$

2-[(6,6-Dimethyl-bicyclo[3.1.1]hept-2-en-2-ylmethyl)-amino]-3-(4-hydroxy-phenyl)propionic acid methyl ester (2f). To a solution of L-tyrosine methyl ester hydrochloride $(0.60 \mathrm{~g}, 2.6 \mathrm{mmol})$ and $\mathrm{MgSO}_{4}(0.778 \mathrm{~g}, 4.2 \mathrm{mmol})$ in anhydrous THF (15 mL) were added (1R)-(-)-myrtenal $(0.79 \mathrm{~mL}, 5.2 \mathrm{mmol})$, and $\mathrm{Et}_{3} \mathrm{~N}(0.43 \mathrm{~mL}, 3.1 \mathrm{mmol})$, and the reaction was left to stir at $\mathrm{rt}$ for $5 \mathrm{~h}$. The reaction mixture was filtered, then concentrated in vacuo to yield the crude imine. The crude imine was then dissolved in $15 \mathrm{~mL}$ methanol, and $\mathrm{NaBH}_{4}(0.196 \mathrm{~g}, 5.18 \mathrm{mmol})$ added to it slowly. The mixture was stirred at $\mathrm{rt}$ for $30 \mathrm{~min}$, then quenched with $10 \mathrm{~mL} 1 \mathrm{~N} \mathrm{NH}_{4} \mathrm{Cl}$, concentrated under reduced pressure, reconstituted with $10 \mathrm{~mL}$ water, and extracted with $3 \times 25 \mathrm{~mL}$ ethyl acetate, then worked up as in the general procedure to yield $0.576 \mathrm{~g}(67.5 \%)$ of 2 f. ${ }^{1} \mathrm{H} \mathrm{NMR}(500$ $\left.\mathrm{MHz}, \mathrm{CD}_{3} \mathrm{OD}\right): \delta 0.82(0.19 \mathrm{H}, \mathrm{s}), 0.84(3 \mathrm{H}, \mathrm{s}), 1.14(1 \mathrm{H}, \mathrm{d}, \mathrm{J}=8.5 \mathrm{~Hz}), 1.27(0.19 \mathrm{H}, \mathrm{s})$, $1.29(3 \mathrm{H}, \mathrm{s}), 2.05-2.11(2 \mathrm{H}, \mathrm{m}), 2.21-2.32(2 \mathrm{H}, \mathrm{q}, J=14.8 \mathrm{~Hz}), 2.37-2.43(1 \mathrm{H}, \mathrm{m}), 2.86$ $(2 \mathrm{H}, \mathrm{d}, \mathrm{J}=6.5 \mathrm{~Hz}), 2.98(1 \mathrm{H}, \mathrm{d}, \mathrm{J}=14 \mathrm{~Hz}), 3.11(1 \mathrm{H}, \mathrm{d}, \mathrm{J}=13.5 \mathrm{~Hz}), 3.37(2 \mathrm{H}, \mathrm{s}), 3.49$ $(1 \mathrm{H}, \mathrm{t}, \mathrm{J}=7 \mathrm{~Hz}), 3.63(3 \mathrm{H}, \mathrm{s}), 3.66(0.17 \mathrm{H}, \mathrm{s}), 5.34(1 \mathrm{H}, \mathrm{s}), 6.72(2 \mathrm{H}, \mathrm{d}, \mathrm{J}=8 \mathrm{~Hz}), 6.99$ $(2 \mathrm{H}, \mathrm{d}, \mathrm{J}=9 \mathrm{~Hz})$. ESI-MS: (+) $330.3(\mathrm{M}+1), 352.2(\mathrm{M}+23) ;(-) 328.0(\mathrm{M}-1)$.

General procedure for $\mathbf{N}$-acetoacetyl amino esters (3a-f). Secondary amine (2a-f) was dissolved in $\mathrm{CH}_{2} \mathrm{Cl}_{2}$, to which 1 equivalent of $50 \%$ diketene in $\mathrm{CH}_{2} \mathrm{Cl}_{2}$ and 5 drops $\mathrm{Et}_{3} \mathrm{~N}$ were added. The mixture was allowed to reflux at $45^{\circ} \mathrm{C}$ for a minimum of $5 \mathrm{~h}$, then allowed to cool to rt and diluted with $\mathrm{CH}_{2} \mathrm{Cl}_{2}$, acidified with $1 \mathrm{~N} \mathrm{HCl}$, and extracted. The organic layer was rinsed with water, dried with $\mathrm{Na}_{2} \mathrm{SO}_{4}$, filtered, and concentrated in vacuo. The crude product was purified via flash chromatography, employing a petroleum ether/ethyl acetate gradient.

6-tert-Butoxycarbonylamino-2-[(4-phenyl-benzyl)-(3-oxo-butyryl)-amino]-hexanoic acid methyl ester (3a). To a solution of $\mathbf{2 a}(0.531 \mathrm{~g}, 1.24 \mathrm{mmol})$ in dichloromethane were added $50 \%$ diketene in dichloromethane $(210 \mu \mathrm{L}, 1.24 \mathrm{mmol})$ and 5 drops of $\mathrm{Et}_{3} \mathrm{~N}$. The mixture was allowed to reflux at $45^{\circ} \mathrm{C}$ overnight, then allowed to cool, diluted with $20 \mathrm{~mL}$ dichloromethane, quenched with $1 \mathrm{~N} \mathrm{HCl}$, and then the organic component washed twice with water before being worked up as in the general procedure to yield $0.502 \mathrm{~g}(79.0 \%)$ of 3a as syrup. ${ }^{1} \mathrm{H}$ NMR $\left(500 \mathrm{MHz}, \mathrm{CD}_{3} \mathrm{OD}\right): \delta 1.18-1.48(13.12 \mathrm{H}, \mathrm{m})$, 1.70-1.86 (1H, m), $1.88(1 \mathrm{H}, \mathrm{s}), 1.93-2.10(1.43 \mathrm{H}, \mathrm{m}), 2.20(1.13 \mathrm{H}, \mathrm{s}), 2.3(0.48 \mathrm{H}, \mathrm{s})$, 2.86-3.05 (2H, m), $3.37(1.45 \mathrm{H}, \mathrm{s}), 3.49-3.55(0.73 \mathrm{H}, \mathrm{m}), 3.60(2.22 \mathrm{H}, \mathrm{d}, J=10.5 \mathrm{~Hz})$, 3.63-3.82 (0.89H, m), 4.37-4.51 (0.58H, m), 4.53-4.76 (2.35H, m), $4.85(2.29 \mathrm{H}, \mathrm{s}), 5.28-$ $5.31(0.32 \mathrm{H}, \mathrm{s}), 7.30-7.48(5 \mathrm{H}, \mathrm{m}), 7.52-7.69(4 \mathrm{H}, \mathrm{m})$. ESI-MS: $533.3(\mathrm{M}+23)$.

6-tert-Butoxycarbonylamino-2-[1-(6,6-dimethyl-bicyclo[3.1.1]hept-2-en-2-yl)-2,4dioxo-pentylamino]-hexanoic acid methyl ester (3b). To a solution of $\mathbf{2 b}(0.210 \mathrm{~g}$, $0.402 \mathrm{mmol})$ in dichloromethane $(10 \mathrm{~mL})$ were added $50 \%$ diketene in dichloromethane $(89.5 \mu \mathrm{L}, 0.402 \mathrm{mmol})$ and $5 \mathrm{drops}$ of $\mathrm{Et}_{3} \mathrm{~N}$. The mixture was allowed to reflux at $45^{\circ} \mathrm{C}$ for $5 \mathrm{~h}$, then allowed to cool to room temperature prior to adding $20 \mathrm{~mL} \mathrm{CH}_{2} \mathrm{Cl}_{2}$, then 10 $\mathrm{mL}$ of $1 \mathrm{~N} \mathrm{NaOH}$, followed by $20 \mathrm{~mL} 1 \mathrm{~N} \mathrm{HCl}$. The organic layer was separated and 
washed with $2 \times 10 \mathrm{~mL}$ water, and then, the combined aqueous portions were back extracted with $2 \times 20 \mathrm{~mL} \mathrm{CH}_{2} \mathrm{Cl}_{2}$. The organic layers were then worked up as in the general procedure to afford $0.12 \mathrm{~g}(47.1 \%)$ of $\mathbf{3 b}$ as a colorless oil. ${ }^{1} \mathrm{H}$ NMR $(500 \mathrm{MHz}$, $\left.\mathrm{CDCl}_{3}\right): \delta 0.83(3 \mathrm{H}, \mathrm{d}, J=9 \mathrm{~Hz}), 1.12(1.05 \mathrm{H}, \mathrm{t}, J=9.25 \mathrm{~Hz}), 1.24-1.27(0.47 \mathrm{H}, \mathrm{d}, J=6$ $\mathrm{Hz}), 1.29(3 \mathrm{H}, \mathrm{s}), 1.33-1.43(2.10 \mathrm{H}, \mathrm{m}), 1.41-1.47(9.27 \mathrm{H}, \mathrm{m}), 1.47-1.54(2.15 \mathrm{H}, \mathrm{m})$, 1.67-1.78 $(1.87 \mathrm{H}, \mathrm{m}), 1.90-1.99(2.93 \mathrm{H}, \mathrm{m}), 2.11-2.16(1 \mathrm{H}, \mathrm{bs}), 2.17(0.77 \mathrm{H}, \mathrm{s}), 2.2-2.34$ (3.68, m), 2.38-2.44 $(1 \mathrm{H}, \mathrm{m}), 3.06-3.15(2 \mathrm{H}, \mathrm{bs}), 3.52-3.54(1.33 \mathrm{H}, \mathrm{s}), 3.55-3.63(0.95 \mathrm{H}$, $\mathrm{m}), 3.68(3 \mathrm{H}, \mathrm{s}), 3.69-3.72(0.38 \mathrm{H}, \mathrm{d}, J=11.5 \mathrm{~Hz}), 3.81-3.90(0.94 \mathrm{H}, \mathrm{m}), 4.68(0.66 \mathrm{H}, \mathrm{t}$, $J=7 \mathrm{~Hz}), 4.77-4.82(0.29 \mathrm{H}, \mathrm{t}, J=7 \mathrm{~Hz}), 5.02(0.32 \mathrm{H}, \mathrm{s}), 5.32-5.37(0.30, \mathrm{bs}), 5.38-5.43$ $(0.62$, bs). ESI-MS: $501.2(\mathrm{M}+23)$.

6-tert-Butoxycarbonylamino-2-[decyl-(3-oxo-butyryl)-amino]-hexanoic acid methyl ester (3c). To a solution of $2 \mathbf{c}(0.671 \mathrm{~g}, 1.68 \mathrm{mmol})$ in dichloromethane $(35 \mathrm{~mL})$ were added $50 \%$ diketene in dichloromethane $(0.28 \mathrm{~mL}, 1.68 \mathrm{mmol})$ and 10 drops of $\mathrm{Et}_{3} \mathrm{~N}$. The mixture was allowed to reflux at $45^{\circ} \mathrm{C}$ for $7 \mathrm{~h}$, then allowed to cool to rt, and diluted with $40 \mathrm{~mL} \mathrm{CH}_{2} \mathrm{Cl}_{2}$. To the mixture was added $10 \mathrm{~mL}$ of $1 \mathrm{~N} \mathrm{HCl}$; the aqueous and organic layers were separated and the organic layer washed with $2 \times 20 \mathrm{~mL}$ water. The combined aqueous layers were then back extracted with $2 \times 40 \mathrm{~mL} \mathrm{CH} \mathrm{Cl}_{2}$. The reaction mixture was then worked up as in the general procedure to yield $0.463 \mathrm{~g}(57.0 \%)$ of $\mathbf{3 c}$ as a yellow amorphous solid. ${ }^{1} \mathrm{H}$ NMR $\left(500 \mathrm{MHz}, \mathrm{CDCl}_{3}\right): \delta 0.69-0.77(3 \mathrm{H}, \mathrm{t}, \mathrm{J}=7 \mathrm{~Hz})$, $1.02-1.42(28.34 \mathrm{H}, \mathrm{m}), 1.42-1.76(1.09 \mathrm{H}, \mathrm{m}), 1.76-1.83(1 \mathrm{H}, \mathrm{s}), 1.83-1.97(1.08 \mathrm{H}, \mathrm{m})$, $2.07(0.77 \mathrm{H}, \mathrm{s}), 2.11(2 \mathrm{H}, \mathrm{s}), 2.86-3.04(2.23 \mathrm{H}, \mathrm{m}), 3.10-3.22(0.89 \mathrm{H}, \mathrm{m}), 3.31-3.48$ $(1.34 \mathrm{H}, \mathrm{m}), 3.48-3.60(3.18 \mathrm{H}, \mathrm{m}), 3.78-3.83(0.44 \mathrm{H}, \mathrm{bs}), 4.05-4.20(0.58 \mathrm{H}, \mathrm{m}), 4.41-4.52$ $(0.22 \mathrm{H}, \mathrm{m}), 4.79-4.95(0.80 \mathrm{H}, \mathrm{m})$. ESI-MS: $507.3(\mathrm{M}+23)$.

6-tert-Butoxycarbonylamino-2-[(4-ethyl-benzyl)-(3-oxo-butyryl)-amino]-hexanoic acid methyl ester (3d). To a solution of $2 \mathbf{d}(0.248 \mathrm{~g}, 0.655 \mathrm{mmol})$ in dichloromethane $(12 \mathrm{~mL})$ were added $50 \%$ diketene in dichloromethane $(111 \mu \mathrm{L}, 0.655 \mathrm{mmol})$ and 5 drops of $\mathrm{Et}_{3} \mathrm{~N}$. The mixture was allowed to reflux at $45^{\circ} \mathrm{C}$ for $7 \mathrm{~h}$, then allowed to cool and diluted with $15 \mathrm{~mL} \mathrm{CH}_{2} \mathrm{Cl}_{2}$, then washed with $5 \mathrm{~mL}$ of $1 \mathrm{~N} \mathrm{HCl}$, followed by $2 \times 10 \mathrm{~mL}$ $\mathrm{H}_{2} \mathrm{O}$. The material was then worked up as in the general procedure. The material was then reacted again, employing $90 \mu \mathrm{L}(0.046 \mathrm{~g}, 0.545 \mathrm{mmol})$, of $50 \%$ diketene in dichloromethane, several drops of $\mathrm{Et}_{3} \mathrm{~N}$, and $10 \mathrm{~mL}$ dichloromethane; the reaction refluxed at $45^{\circ} \mathrm{C}$ for $10 \mathrm{~h}$, then cooled and diluted with $20 \mathrm{~mL} \mathrm{CH}_{2} \mathrm{Cl}_{2}$ and washed with $10 \mathrm{~mL} 1 \mathrm{~N} \mathrm{HCl}$, followed by $2 \times 10 \mathrm{~mL} \mathrm{H}_{2} \mathrm{O}$ and worked up as in the general procedure without chromatography to give 3d in an overall yield of $0.186 \mathrm{~g}(61.4 \%)$. ${ }^{1} \mathrm{H}$ NMR (500 $\left.\mathrm{MHz}, \mathrm{CD}_{3} \mathrm{OD}\right): 1.20-1.30(3.69 \mathrm{H}, \mathrm{m}), 1.30-1.44(3.22 \mathrm{H}, \mathrm{m}), 1.50(9.42 \mathrm{H}, \mathrm{d}, J=28 \mathrm{~Hz})$, $1.68-1.85(1.17 \mathrm{H}, \mathrm{m}), 1.91(0.63 \mathrm{H}, \mathrm{s}), 1.95-2.09(1 \mathrm{H}, \mathrm{m}), 2.21(1.18 \mathrm{H}, \mathrm{s}), 2.31(0.44 \mathrm{H}$, s), $2.60-2.71(2 \mathrm{H}, \mathrm{m}), 2.88-3.08(2 \mathrm{H}, \mathrm{m}), 3.53(0.57 \mathrm{H}, \mathrm{s}),(1.9 \mathrm{H}),, 3.65-3.74(0.50 \mathrm{H}, \mathrm{m})$, $3.75(0.49 \mathrm{H}, \mathrm{s}), 3.76-3.93(0.31 \mathrm{H}, \mathrm{m}), 4.35-4.41(0.42 \mathrm{H}, \mathrm{m}) 4.46-4.72(2.27 \mathrm{H}, \mathrm{m}), 5.32$ $(0.13 \mathrm{H}, \mathrm{s}), 6.36-6.52(0.50 \mathrm{H}, \mathrm{m}), 7.12-7.32(4 \mathrm{H}, \mathrm{m})$. ESI-MS: $485.3(\mathrm{M}+23)$.

6-tert-Butoxycarbonylamino-2-[(4-methoxy-benzyl)-(3-oxo-butyryl)-amino]hexanoic acid methyl ester (3e). To a solution of $2 \mathrm{e}(0.152 \mathrm{~g}, 0.399 \mathrm{mmol})$ in dichloromethane $(10 \mathrm{~mL})$ were added $50 \%$ diketene in dichloromethane $(67 \mu \mathrm{L}, 0.399$ $\mathrm{mmol}$ ). The mixture was allowed to reflux at $45^{\circ} \mathrm{C}$ for $18 \mathrm{~h}$; then, 13 drops of $\mathrm{Et}_{3} \mathrm{~N}$ and 
an additional $67 \mu \mathrm{L}$ diketene were added, and the reaction refluxed a further $24 \mathrm{~h}$ at $45^{\circ} \mathrm{C}$, then allowed to cool to near room temperature. $10 \mathrm{~mL}$ of $1 \mathrm{~N} \mathrm{HCl}$ were added to the mixture, then $20 \mathrm{~mL} \mathrm{CH}_{2} \mathrm{Cl}_{2}$. The organic layer was separated and washed with $2 \times 10$ $\mathrm{mL}$ water, then worked up as in the general procedure to afford $0.186 \mathrm{~g}(61.4 \%)$ of $3 \mathbf{e}$. ${ }^{1} \mathrm{H}$ NMR (500 MHz): $\delta 1.10-1.54(12.34 \mathrm{H}, \mathrm{m}), 1.68-1.84(0.93 \mathrm{H}, \mathrm{m}), 1.90(0.81 \mathrm{H}, \mathrm{s})$, 1.93-2.08 (1.2H, m), 2.13-2.32 (2.2H, m), 2.57-2.63 $(0.5 \mathrm{H}, \mathrm{m}), 2.87-3.02(1.67 \mathrm{H}, \mathrm{m})$, 3.32-3.35 (0.5H, m), $3.37(0.45 \mathrm{H}, \mathrm{s}), 3.50-3.54(0.47 \mathrm{H}, \mathrm{s}), 3.56-3.63(1.64 \mathrm{H}, \mathrm{m}), 3.63-$ $3.75(0.89 \mathrm{H}, \mathrm{m}), 3.75-3.89(3.56 \mathrm{H}, \mathrm{m}), 4.27-4.33(0.34 \mathrm{H}, \mathrm{m}), 4.38-4.64(2.13 \mathrm{H}, \mathrm{m}), 4.85$ $(2.45 \mathrm{H}, \mathrm{s}), 4.90-5.04(0.31 \mathrm{H}, \mathrm{m}), 6.75-6.98(2.1 \mathrm{H}, \mathrm{m}), 7.16-7.34(2 \mathrm{H}, \mathrm{m})$. ESI-MS: $487.3(\mathrm{M}+23)$.

2-[(6,6-Dimethyl-bicyclo[3.1.1] hept-2-en-2-ylmethyl)-(3-oxo-butyryl)-amino]-3-(4hydroxy-phenyl)-propionic acid methyl ester (3f). To a solution of $\mathbf{2 f}(0.576 \mathrm{~g}, 1.75$ $\mathrm{mmol})$ in anhydrous $\mathrm{CHCl}_{3}(30 \mathrm{~mL})$ were added $50 \%$ diketene in dichloromethane $(296$ $\mu \mathrm{L}, 1.76 \mathrm{mmol}$ ) and several drops of $\mathrm{Et}_{3} \mathrm{~N}$. The reaction was refluxed at $45^{\circ} \mathrm{C}$ for $9 \mathrm{~h}$, then allowed to cool to rt, diluted with $40 \mathrm{~mL} \mathrm{CHCl}_{3}$ and extracted with $10 \mathrm{~mL}$ water combined with $10 \mathrm{~mL}$ of $1 \mathrm{~N} \mathrm{HCl}$ solution. The aqueous layer was extracted with $2 \times 40$ $\mathrm{mL} \mathrm{CHCl}_{3}$, and the combined organic layers worked up as in the general procedure to yield $0.287 \mathrm{~g}(39.7 \%) 3 \mathrm{f}$ as a brown gel. ${ }^{1} \mathrm{H} \mathrm{NMR}\left(500 \mathrm{MHz}, \mathrm{CD}_{3} \mathrm{OD}\right): \delta 0.82(2.06 \mathrm{H}$, s), $0.84(0.68 \mathrm{H}, \mathrm{s}), 0.87(0.13 \mathrm{H}, \mathrm{s}), 1.09-1.13(0.93 \mathrm{H}, \mathrm{m}), 1.30(3 \mathrm{H}, \mathrm{s}), 1.92(0.60 \mathrm{H}, \mathrm{s})$, 1.97-2.02 $(0.88 \mathrm{H}$, broad triplet, $J=5.25 \mathrm{~Hz}), 2.033(0.12 \mathrm{H}, \mathrm{s}), 2.06-2.10(1.01 \mathrm{H}, \mathrm{bs})$, $2.15(0.12 \mathrm{H}, \mathrm{s}), 2.19(0.18 \mathrm{H}, \mathrm{s}), 2.21(2.19 \mathrm{H}, \mathrm{s}), 2.22-2.25(0.63 \mathrm{H}, \mathrm{bs}), 2.27-2.30(0.56 \mathrm{H}$, bs), 2.30-2.34 (0.23H, bs), 2.38-2.44 (1 H, m), $2.99(0.83 \mathrm{H}, \mathrm{d}, J=17 \mathrm{~Hz}), 3.03(0.12 \mathrm{H}$, s), 3.07-3.15 $(1 \mathrm{H}, \mathrm{m}), 3.17-3.26(1 \mathrm{H}, \mathrm{m}), 3.37(4.45 \mathrm{H}, \mathrm{s}), 3.51-3.62(1.36 \mathrm{H}, \mathrm{q}, J=15.2$ $\mathrm{Hz}), 3.66(0.62, \mathrm{~s}), 3.68(2.09 \mathrm{H}, \mathrm{s}), 3.70(0.13 \mathrm{H}, \mathrm{s}), 3.70-3.73(0.48, \mathrm{bs}), 3.74-3.77$ $(0.44 \mathrm{H}, \mathrm{bs}), 4.29(0.69 \mathrm{H}, \mathrm{dd}, J=5.17 \mathrm{~Hz}), 5.13(0.18 \mathrm{H}, \mathrm{s}), 5.23(0.24 \mathrm{H}, \mathrm{s}), 5.30(0.66, \mathrm{~s})$, 6.69-6.78 $(1.89 \mathrm{H}, \mathrm{m}), 7.01(0.43 \mathrm{H}, \mathrm{d}, J=9 \mathrm{~Hz}), 7.7 .08(1.48 \mathrm{H}, \mathrm{d}, J=8.5 \mathrm{~Hz})$. ESI-MS: $414.3(\mathrm{M}+1), 436.3(\mathrm{M}+23)$.

General procedure for formation of tetramic acids $\mathbf{4 b}$-e and 6 . To a flask containing the diketone, $5 \mathrm{~mL}$ warmed $t$-butanol was added. The flask was kept at $40^{\circ} \mathrm{C}$ to prevent the solvent from solidifying, and to it was added 3 equivalents of either sodium or potassium tert-butoxide, gradually. The reaction mixture was stirred for $1 \mathrm{~h}$, then water and excess $1 \mathrm{~N} \mathrm{HCl}$ solution were added. The neutralized mixture was extracted with $\mathrm{CH}_{2} \mathrm{Cl}_{2}$, dried with $\mathrm{Na}_{2} \mathrm{SO}_{4}$, filtered, and concentrated in vacuo.

(4-[1-(4-phenyl-benzyl)-4-(1-hydroxy-ethylidene)-3,5-dioxo-pyrrolidin-2-yl]-butyl)carbamic acid tert-butyl ester (4a). A quantity of $t$-butanol was thawed, and was added to $0.283 \mathrm{~g}$ of sodium $t$-butoxide. The base dissolved poorly in the solvent, but suspended solid was added via Pasteur pipet into a flask containing $0.502 \mathrm{~g} \mathrm{3a}$, kept stirring at $40^{\circ} \mathrm{C}$. Approximately half the base could be added to the reaction mixture; the amount of time spent in the addition was approximately $40 \mathrm{~min}$. To the reaction mixture was added water and $1 \mathrm{~N} \mathrm{HCl}$, and the mixture extracted with $\mathrm{CH}_{2} \mathrm{Cl}_{2}$. Yield: $0.114 \mathrm{~g}, 24.2 \%$. ${ }^{1} \mathrm{H}$ NMR (500MHz, CD $\left.3 \mathrm{OD}\right): \delta 1.24(0.73 \mathrm{H}, \mathrm{s}), 1.26-1.39(2.40 \mathrm{H}, \mathrm{m}), 1.43(9.24 \mathrm{H}, \mathrm{s})$, 1.72-1.80 (2H, m), $2.01(0.29 \mathrm{H}, \mathrm{s}), 2.46(2.45 \mathrm{H}, \mathrm{s}), 2.92-2.98(2 \mathrm{H}, \mathrm{m}), 3.37(9.70 \mathrm{H}, \mathrm{s})$, 
$7.33(1 \mathrm{H}, \mathrm{t}, J=7.25 \mathrm{~Hz}), 7.38-7.46(4 \mathrm{H}, \mathrm{m}), 7.58-7.63(4 \mathrm{H}, \mathrm{m})$. ESI-MS: 501.2 $(\mathrm{M}+23)$. HPLC1: $254 \mathrm{~nm} t_{\mathrm{R}} 7.13 \mathrm{~min}$, purity $41 \%$.

(4-[1-(6,6-Dimethyl-bicyclo[3.1.1]hept-2-en-2-ylmethyl)-4-(1-hydroxy-ethylidene)3,5-dioxo-pyrrolidin-2-yl]-butyl)-carbamic acid tert-butyl ester (4b). A portion of $t$ butanol was thawed, and a quantity $(5 \mathrm{~mL})$ of it was added to $\mathbf{3 b}(0.109 \mathrm{~g}, 0.225 \mathrm{mmol})$. To this solution was added potassium $t$-butoxide $(0.070 \mathrm{~g}, 0.724 \mathrm{mmol})$, slowly. The reaction was stirred for $1 \mathrm{~h}$ at $40^{\circ} \mathrm{C}$, then $8 \mathrm{~mL}$ water and $8 \mathrm{~mL}$ of $1 \mathrm{~N} \mathrm{HCl}$ were added. The reaction was extracted with $3 \times 20 \mathrm{~mL} \mathrm{CH}_{2} \mathrm{Cl}_{2}$, then worked up as in the general procedure to yield $0.097 \mathrm{~g}(95.7 \%)$ of product as yellow gel. ${ }^{1} \mathrm{H}$ NMR $(500 \mathrm{MHz}$, $\left.\mathrm{CDCl}_{3}\right): \delta 0.78(0.41 \mathrm{H}, \mathrm{s}), 0.83(3 \mathrm{H}, \mathrm{s}), 1.02(1 \mathrm{H}, \mathrm{d}, J=9 \mathrm{~Hz}), 1.07-1.16(1.28 \mathrm{H}, \mathrm{m})$, $1.22-1.30(4.94, \mathrm{~m}), 1.40-1.52(12.64 \mathrm{H}, \mathrm{m}), 1.68-1.79(1.14 \mathrm{H}, \mathrm{m}), 1.84-1.94(1.14 \mathrm{H}, \mathrm{m})$, $1.97(0.94 \mathrm{H}, \mathrm{t}, J=5 \mathrm{~Hz}), 2.03(0.27 \mathrm{H}, \mathrm{s}), 2.06-2.12(1.24 \mathrm{H}, \mathrm{m}), 2.18-2.22(0.35 \mathrm{H}, \mathrm{m})$, 2.22-2.25 (0.83H, m), 2.27-2.31 (0.79H, m), 2.31-2.37 (1.33H, m), $2.43(2.64 \mathrm{H}, \mathrm{s}), 2.52$ $(0.41 \mathrm{H}, \mathrm{s}), 3.00-3.15(2.31 \mathrm{H}, \mathrm{m}), 3.30(0.81 \mathrm{H}, \mathrm{d}, J=14.5 \mathrm{~Hz}), 3.63-3.68(0.82 \mathrm{H}, \mathrm{m})$, $3.72-3.84(0.29 \mathrm{H}, \mathrm{m}), 4.11(0.18 \mathrm{H}, \mathrm{q}, J=7.5 \mathrm{~Hz}), 4.49-4.64(2 \mathrm{H}, \mathrm{m}), 5.39-5.48(0.24 \mathrm{H}$, m), $5.50(0.85 \mathrm{H}, \mathrm{s})$. ESI-MS: (+) $469.2(\mathrm{M}+23),(-) 445.1(\mathrm{M}-1)$. HPLC2: $254 \mathrm{~nm} t_{\mathrm{R}}$ 3.20 min, purity $99 \%$.

(4-[1-Decyl-4-(1-hydroxy-ethylidene)-3,5-dioxo-pyrrolidin-2-yl]-butyl)-carbamic acid tert-butyl ester (4c). A portion of $t$-butanol was thawed, and a quantitiy $(8 \mathrm{~mL})$ of it was added to $3 \mathbf{c}(0.442 \mathrm{~g}, 0.912 \mathrm{mmol})$. To this solution was added potassium $t$ butoxide $(0.307 \mathrm{~g}, 2.74 \mathrm{mmol})$, slowly. The reaction was stirred for $2 \mathrm{~h}$ at $35^{\circ} \mathrm{C}$, then 20 $\mathrm{mL}$ water and $20 \mathrm{~mL}$ of $1 \mathrm{~N} \mathrm{HCl}$ were added. The solution was extracted with $40 \mathrm{~mL}$, then $3 \times 30 \mathrm{~mL} \mathrm{CH} \mathrm{Cl}_{2}$, then worked up as in the general procedure to yield $0.405 \mathrm{~g}$ $(98.3 \%)$ of product as dark brown oil. ${ }^{1} \mathrm{H} \mathrm{NMR}\left(500 \mathrm{MHz}, \mathrm{CDCl}_{3}\right): \delta 0.83(3 \mathrm{H}, \mathrm{t}, J=7$ $\mathrm{Hz}), 1.03-1.14(1.28 \mathrm{H}, \mathrm{m}), 1.14-1.32(14.1 \mathrm{H}$, closely spaced uneven peaks), 1.34-1.61 $(10.75 \mathrm{~Hz}$, two single peaks among a multiplet), 1.66-1.75 $(0.76 \mathrm{H}, \mathrm{m}), 1.84-1.96(0.84 \mathrm{H}$, m), $1.99(0.17 \mathrm{H}), 2.17(0.5 \mathrm{H}, \mathrm{s}), 2.27(0.17 \mathrm{H}, \mathrm{t}, J=7.5 \mathrm{~Hz}), 2.38(2 \mathrm{H}, \mathrm{s}), 2.47(0.23 \mathrm{H}$, bs), 2.83-3.08 $(2.05 \mathrm{H}, \mathrm{m}), 3.58-3.65(0.39 \mathrm{H}, \mathrm{m}), 3.73-3.83(1.38 \mathrm{H}, \mathrm{m}), 3.86-3.96(0.41 \mathrm{H}$, $\mathrm{m}), 4.70(0.39 \mathrm{H}, \mathrm{bs})$. ESI-MS: $475.3(\mathrm{M}+23)$. HPLC2: $254 \mathrm{~nm} t_{\mathrm{R}} 4.38 \mathrm{~min}$, purity $79 \%$.

(4-[1-(4-Ethyl-benzyl)-4-(1-hydroxy-ethylidene)-3,5-dioxo-pyrrolidin-2-yl]-butyl)carbamic acid tert-butyl ester (4d). A portion of $t$-butanol was thawed, and a quantity $(5 \mathrm{~mL})$ of it was added to $3 \mathbf{d}(0.186 \mathrm{~g}, 0.402 \mathrm{mmol})$. To this solution was added sodium $t$-butoxide $(0.116 \mathrm{~g}, 1.206 \mathrm{mmol})$, slowly. The reaction was stirred for $1.5 \mathrm{~h}$ at $40^{\circ} \mathrm{C}$, then $10 \mathrm{~mL} 1 \mathrm{~N} \mathrm{HCl}$ was added. The solution was extracted with 3 x $25 \mathrm{~mL} \mathrm{CH}_{2} \mathrm{Cl}_{2}$, then worked up as in the general procedure to yield $0.078 \mathrm{~g}(43.9 \%)$ of product as dark orange oil. ${ }^{1} \mathrm{H}$ NMR $(500 \mathrm{MHz}): 0.92(0.37 \mathrm{H}, \mathrm{q}, J=7 \mathrm{~Hz}), 1.00-1.11(1 \mathrm{H}, \mathrm{m}), 1.11-$ $1.18(0.81 \mathrm{H}, \mathrm{m}), 1.21(3 \mathrm{H}, \mathrm{t}, J=7.5 \mathrm{~Hz}), 1.24(0.52 \mathrm{H}, \mathrm{s}), 1.29(0.5 \mathrm{H}, \mathrm{s}), 1.30-1.41$ $(1.69 \mathrm{H}, \mathrm{m}), 1.44(6.37 \mathrm{H}, \mathrm{s}), 1.47(1.78 \mathrm{H}, \mathrm{s}), 1.50(0.41 \mathrm{H}, \mathrm{d}, J=6.5 \mathrm{~Hz}), 1.69-1.89$ $(1.89 \mathrm{H}, \mathrm{m}), 2.21(0.66 \mathrm{H}, \mathrm{s}), 2.44(2.32 \mathrm{H}, \mathrm{s}), 2.62(2 \mathrm{H}, \mathrm{q}, J=7.5 \mathrm{~Hz}), 2.94(1.27 \mathrm{H}, \mathrm{m})$, $3.33(0.29 \mathrm{H}, \mathrm{s}), 3.37(2 \mathrm{H}, \mathrm{s}), 3.59(0.42 \mathrm{H}, \mathrm{t}, J=6.25 \mathrm{~Hz}), 3.97(0.42 \mathrm{H}, \mathrm{q}, J=12.5 \mathrm{~Hz})$, $4.26(0.81 \mathrm{H}, \mathrm{t}, J=14 \mathrm{~Hz}), 4.92\left(1 \mathrm{H}, \mathrm{dd}, J_{l}=15 \mathrm{~Hz}, J_{2}=5.5 \mathrm{~Hz}\right), 5.03(2.92 \mathrm{H}, \mathrm{bs}), 7.18$ $(2 \mathrm{H}, \mathrm{d}, J=7.5 \mathrm{~Hz}), 7.24(2 \mathrm{H}, \mathrm{d}, J=7.5 \mathrm{~Hz})$ ESI-MS: (+) $485.3(\mathrm{M}+23),(-) 451.1(\mathrm{M}-$ 1). HPLC1: $254 \mathrm{~nm} t_{\mathrm{R}} 7.25 \mathrm{~min}$, purity $84 \%$. 
(4-[4-(1-Hydroxy-ethylidene)-1-(4-methoxy-benzyl)-3,5-dioxo-pyrrolidin-2-yl]butyl)-carbamic acid tert-butyl ester (4e). A portion of $t$-butanol was thawed, and a quantity $(5 \mathrm{~mL})$ of it was added to $3 \mathrm{e}(0.112 \mathrm{~g}, 0.241 \mathrm{mmol})$. To this solution was added sodium $t$-butoxide $(0.070 \mathrm{~g}, 0.724 \mathrm{mmol})$, slowly. The reaction was stirred for $1 \mathrm{~h}$, then 8 $\mathrm{mL}$ water and $1 \mathrm{~N} \mathrm{HCl}$ were added. The solution was extracted with $3 \times 25 \mathrm{~mL} \mathrm{CH} \mathrm{Cl}_{2}$, then worked up as in the general procedure to give the product in quantitative yield (0.108 g). ${ }^{1} \mathrm{H}$ NMR (500 MHz, CD $\left.{ }_{3} \mathrm{OD}\right): \delta 0.80-0.87$ (0.62H, q, $\left.J=9 \mathrm{~Hz}\right), 0.90-1.13$ $(2.0 \mathrm{H}, \mathrm{m}), 1.16(1.37 \mathrm{H}, \mathrm{s}), 1.18-1.42(11.78 \mathrm{H} ; \mathrm{m}$, but with a singlet at 1.352$), 1.62-1.80$ $(1.94 \mathrm{H}, \mathrm{m}), 2.13(0.20, \mathrm{H}, \mathrm{s}), 2.20(0.22 \mathrm{H}, \mathrm{s}), 2.36(2.22 \mathrm{H}, \mathrm{s}), 2.82-2.90(1.67 \mathrm{H}, \mathrm{m}), 3.24$ $(0.58 \mathrm{H}$, quintet, $J=1.5 \mathrm{~Hz}), 3.28(0.92 \mathrm{H}, \mathrm{s}), 3.63(0.73 \mathrm{H}, \mathrm{bs}), 3.70(3 \mathrm{H}, \mathrm{s}), 4.11(0.73 \mathrm{H}$, $\mathrm{d}, J=14.5 \mathrm{~Hz}), 4.45(0.30 \mathrm{H}, \mathrm{s}), 6.78-6.84(2 \mathrm{H}, \mathrm{m}), 7.13-7.21(2 \mathrm{H}, \mathrm{m})$. ESI-MS: $\left.{ }^{+}\right)$ $455.3(\mathrm{M}+23),(-) 431.0(\mathrm{M}-1)$. HPLC1: $254 \mathrm{~nm} t_{\mathrm{R}} 6.74 \mathrm{~min}$, purity $92 \%$.

1-(6,6-Dimethyl-bicyclo[3.1.1]hept-2-en-2-ylmethyl)-5-(4-hydroxy-benzyl)-3-(1hydroxy-ethylidene)-pyrrolidine-2,4-dione (6). A portion of $t$-butanol was thawed, and a quantity $(12 \mathrm{~mL})$ of it was added to $3 \mathbf{f}(0.287 \mathrm{~g}, 0.693 \mathrm{mmol})$. To this solution was slowly added sodium $t$-butoxide $(0.233 \mathrm{~g}, 2.079 \mathrm{mmol})$. The reaction was stirred for $1 \mathrm{~h}$ at $40^{\circ} \mathrm{C}$, then $10 \mathrm{~mL}$ water and $10 \mathrm{~mL}$ of $1 \mathrm{~N} \mathrm{NaOH}$ were added. The reaction mixture's $\mathrm{pH}$ was brought to approximately 4 with concentrated $\mathrm{HCl}$ solution and potassium $t$ butoxide, then extracted with $3 \times 60 \mathrm{~mL} \mathrm{CHCl}_{3}$, then worked up as in the general procedure to give the product in quantitative yield. ${ }^{1} \mathrm{H}$ NMR $\left(500 \mathrm{MHz}, \mathrm{CD}_{3} \mathrm{OD}\right): \delta 0.81$ $(0.77 \mathrm{H}, \mathrm{s}), 0.87(3 \mathrm{H}, \mathrm{s}), 1.11(1 \mathrm{H}, \mathrm{d}, J=8.5 \mathrm{~Hz}), 1.17(0.29 \mathrm{H}, \mathrm{d}, J=8.5 \mathrm{~Hz}), 1.24$ $(0.51 \mathrm{H}, \mathrm{s}), 1.26(1.19 \mathrm{H}, \mathrm{d}, J=1.5 \mathrm{H}), 1.27(0.28 \mathrm{H}, \mathrm{s}), 1.30(3.16 \mathrm{H}, \mathrm{s}), 1.96(1 \mathrm{H}$, broad triplet, $J=5 \mathrm{~Hz}), 2.03(0.88 \mathrm{H}, \mathrm{s}), 2.05-2.07(0.27 \mathrm{H}, \mathrm{m}), 2.07-2.13(1.34 \mathrm{H}, \mathrm{m}), 2.22-2.25$ $(0.42 \mathrm{H}, \mathrm{m}), 2.26-2.29(1.27 \mathrm{H}, \mathrm{m}), 2.30-2.33(0.86 \mathrm{H}, \mathrm{m}), 2.36(4.20 \mathrm{H}, \mathrm{s}), 2.37-2.46$ $(1.28 \mathrm{H}, \mathrm{m}), 2.98(0.1 \mathrm{H}, \mathrm{d}, J \approx 4.5 \mathrm{~Hz}), 3.00(0.5 \mathrm{H}, \mathrm{t}, J=4.2 \mathrm{~Hz}), 3.03(0.7 \mathrm{H}, J=4.5 \mathrm{~Hz})$, $3.08(0.68 \mathrm{H}, J=4.5 \mathrm{H}), 3.11(0.50 \mathrm{H}, J=4.2), 3.15(0.12 \mathrm{H}, \mathrm{d}, J \approx 4.5 \mathrm{~Hz}), 3.37(9.28 \mathrm{H}$, s), $3.51(0.61 \mathrm{H}$, two close singlets $), 3.58(0.60 \mathrm{H}$, two singlets $), 3.92-3.96(0.91 \mathrm{H}$, bs $)$, 4.05-4.08 $(0.23 \mathrm{H}, \mathrm{bs}), 4.12(0.61 \mathrm{H}, \mathrm{q}, J=7 \mathrm{~Hz}), 4.44-4.52(1.26 \mathrm{H}, \mathrm{m}), 5.32(0.25 \mathrm{H}, \mathrm{s})$, $5.42(1.01 \mathrm{H}, \mathrm{s}), 6.67(2.47 \mathrm{H}, \mathrm{d}, J=8.5 \mathrm{~Hz}), 6.95(2.48 \mathrm{H}, \mathrm{d}, J=8 \mathrm{~Hz}) . \quad$ ESI-MS: 404.2 $(\mathrm{M}+23)$. HPLC3: $254 \mathrm{~nm}, t_{\mathrm{R}} 5.90 \mathrm{~min}$, Purity $98 \%$.

General procedure for primary amine formation from Boc-protected tetramic acids (5a-e). To the corresponding tetramic acid (4a-e) was added THF, followed by approximately 0.5 equivalents TFA. The solution was stirred for $1 \mathrm{~h}$ at $\mathrm{rt}$, then evaporated to dryness.

5-(4-Amino-butyl)-1-biphenyl-4-ylmethyl-3-(1-hydroxy-ethylidene)-pyrrolidine-2,4dione (5a). To $0.114 \mathrm{~g}(0.238 \mathrm{mmol})$ of $4 \mathbf{a}$ were added $1 \mathrm{~mL} \mathrm{THF}$, followed by $1 \mathrm{~mL}$ TFA. The mixture was stirred for $4 \mathrm{~h}$ at $\mathrm{r}$. t., then evaporated. The reaction was then repeated again with $1 \mathrm{~mL}$ THF and $1 \mathrm{~mL}$ TFA overnight, then evaporated to dryness. ${ }^{1} \mathrm{H}$ NMR (300 MHz, $\left.\mathrm{CDOD}_{3}\right): 0.99-1.33(2.48 \mathrm{H}, \mathrm{m}), 1.42(2.33 \mathrm{H}, \mathrm{s}), 1.45-1.64(1.63 \mathrm{H}$, m), 1.71-2.00 (1.94H, m), $2.47(2.32 \mathrm{H}, \mathrm{s}), 2.80(1.31 \mathrm{H}, \mathrm{t}, J=6.75 \mathrm{H}), 2.88-2.98(0.37 \mathrm{H}$, $\mathrm{m}), 3.32(0.71 \mathrm{H}, \mathrm{s}), 3.72-3.87(0.72 \mathrm{H}, \mathrm{m}), 4.26-4.44(0.81 \mathrm{H}, \mathrm{m}), 4.86-5.16(5.73 \mathrm{H}$, 
closely spaced singlets), 7.23-7.49 $(5.03 \mathrm{H}, \mathrm{m}), 7.50-7.71(4 \mathrm{H}, \mathrm{m}), 7.84-7.92(0.42 \mathrm{H}, \mathrm{m})$. ESI-MS: $379.2(\mathrm{M}+1)$. HPLC1: $254 \mathrm{~nm}, t_{\mathrm{R}} 5.42 \mathrm{~min}$, purity $86 \%$.

5-(4-Amino-butyl)-1-(6,6-dimethyl-bicyclo[3.1.1]hept-2-en-2-ylmethyl)-3-(1hydroxy-ethylidene)-pyrrolidine-2,4-dione (5b). To $0.81 \mathrm{~g}(0.182 \mathrm{mmol})$ of $\mathbf{4 b}$ were added $1 \mathrm{~mL}$ THF and $0.5 \mathrm{~mL}$ TFA. The reaction was stirred at $\mathrm{r}$. $\mathrm{t}$. for approximately 1.5 $\mathrm{h}$, then evaporated. The product was then reacted again with $1 \mathrm{~mL}$ THF and $0.5 \mathrm{~mL}$ TFA for $1 \mathrm{~h}$, then evaporated to a dark brown gel. 1H NMR $(500 \mathrm{MHz}): 0.74-0.80(1 \mathrm{H}, \mathrm{m})$, $0.83(3 \mathrm{H}, \mathrm{s}), 0.97-1.06(1 \mathrm{H}, \mathrm{m}), 1.06-1.20(1.93 \mathrm{H}, \mathrm{m}), 1.21-1.31(5 \mathrm{H}$; mainly a single large peak), $1.31-1.38(1.57 \mathrm{H}, \mathrm{m}), 1.46(3.67 \mathrm{H}, \mathrm{s}), 1.60(0.68 \mathrm{H}, \mathrm{s}), 1.63-1.81(4 \mathrm{H}, \mathrm{m})$, $1.81-2.02(6.09 \mathrm{H}, \mathrm{m}), 2.02-2.07(1.28 \mathrm{H}, \mathrm{m}), 2.17(1.74 \mathrm{H}, \mathrm{bs}), 2.18-2.32(2.92 \mathrm{H}, \mathrm{m})$, 2.32-2.40 (1.64H, m), 2.41-2.49 (3.43H; two unequal peaks); $2.53(0.54 \mathrm{H}, \mathrm{t}, J=8 \mathrm{~Hz})$, 2.95-3.12 $(2.12 \mathrm{H}, \mathrm{m}), 3.32(0.87 \mathrm{H}, J=13.2), 3.43(0.46 \mathrm{H}, \mathrm{t}, J=15 \mathrm{~Hz}), 3.64-4.08(5.41$, $\mathrm{m}), 4.08-4.18(0.44 \mathrm{H}, \mathrm{m}), 4.33-4.46(1.12 \mathrm{H}, \mathrm{m}), 4.47-4.57(0.92 \mathrm{H}, \mathrm{m}), 5.41(0.35 \mathrm{H}, \mathrm{s})$, $5.49(0.9 \mathrm{H}, \mathrm{s}), 7.48(1.88 \mathrm{H}, \mathrm{s})$. ESI-MS: $(+) 347.2(\mathrm{M}+1)$. HPLC2: $254 \mathrm{~nm}, t_{\mathrm{R}} 1.68$ min, purity $88 \%$.

5-(4-Amino-butyl)-1-decyl-3-(1-hydroxy-ethylidene)-pyrrolidine-2,4-dione (5c). To $0.392 \mathrm{~g}(0.866 \mathrm{mmol})$ of $\mathbf{4 c}$ were added $3 \mathrm{~mL}$ THF and $2 \mathrm{~mL}$ TFA. The reaction was stirred at $r$. t. for $1 \mathrm{~h}$, then evaporated. The solution was then reacted again with $3 \mathrm{~mL}$ THF and $2 \mathrm{~mL}$ TFA, then evaporated to a somewhat darker brownish oil. Prior to antimicrobial testing, portions of this product were purified by use of a Gilson preparative HPLC reversed-phase column and combined. ${ }^{1} \mathrm{H}$ NMR $\left(500 \mathrm{MHz}, \mathrm{CDCl}_{3}\right): 0.92(3 \mathrm{H}, \mathrm{t})$, $1.08-1.18(0.88 \mathrm{H}, \mathrm{m}), 1.18-1.37(15.41 \mathrm{H}, \mathrm{m}$ dominated by large singlet $), 1.39-1.53$ $(5.75 \mathrm{H}, \mathrm{m}$ including large singlet), 1.54-1.64 $(1.56 \mathrm{H}, \mathrm{m}), 1.66-1.81(1.71 \mathrm{H}, \mathrm{m}), 1.87-2.02$ $(1.75 \mathrm{H}, \mathrm{m}), 2.06(0.81 \mathrm{H}, \mathrm{s}), 2.19(0.19 \mathrm{H}, \mathrm{s}), 2.24-2.29(0.36 \mathrm{H}, \mathrm{m}), 2.29-2.34(0.34 \mathrm{H}, \mathrm{m})$, 2.34-2.36 (0.19H, m), $2.4(2.32 \mathrm{H}, \mathrm{dd}, J=10 \mathrm{~Hz}), 2.98-3.12(2.09 \mathrm{H}, \mathrm{m}), 3.18-3.28$ $(0.36 \mathrm{H}, \mathrm{m}), 3.72-3.90(2.34 \mathrm{H}, \mathrm{m}), 4.12(0.4 \mathrm{H}, \mathrm{q}, J=7.17 \mathrm{~Hz}), 4.23-4.42(0.43 \mathrm{H}, \mathrm{m}), 7.61$ (0.7H, bs). ESI-MS: $475.3(\mathrm{M}+23)$. HPLC3: $254 \mathrm{~nm}, t_{\mathrm{R}} 4.52 \mathrm{~min}$, purity $59 \%$.

5-(4-Amino-butyl)-1-(4-ethyl-benzyl)-3-(1-hydroxy-ethylidene)-pyrrolidine-2,4dione (5d). To $0.078 \mathrm{~g}$ of $\mathbf{4 d}$ were added $1 \mathrm{~mL}$ THF and $0.5 \mathrm{~mL}$ TFA. The reaction was allowed to proceed at $\mathrm{r}$. $\mathrm{t}$. for $11.5 \mathrm{~h}$, then evaporated to form a brown sticky semisolid. ${ }^{1} \mathrm{H}$ NMR (500 MHz, CD $\left.{ }_{3} \mathrm{OD}\right): 0.88-0.94(0.87 \mathrm{H}, \mathrm{m}), 1.01-1.09$ (0.60Hz, m), 1.10-1.18 $(0.79 \mathrm{H}, \mathrm{m}), 1.23(3.60 \mathrm{H}, \mathrm{t}, J=7.5 \mathrm{~Hz}), 1.26-1.39(4.14 \mathrm{H}, \mathrm{m}), 1.44(4 \mathrm{H}, \mathrm{s}), 1.72-1.95$ $(1.93 \mathrm{H}, \mathrm{m}), 2.47(2 \mathrm{H}, \mathrm{s}), 2.65(2 \mathrm{H}, \mathrm{q}, J=7.67 \mathrm{~Hz}), 2.78-2.84(0.42 \mathrm{H}, \mathrm{m}), 2.94(0.67 \mathrm{H}, \mathrm{t}$, $J=6.25), 3.33(2.32 \mathrm{H}, \mathrm{t}, J=1.5 \mathrm{~Hz}), 3.72-3.80(0.66 \mathrm{H}, \mathrm{m}), 4.25-4.31(0.53 \mathrm{H}, \mathrm{d}, J=15$ $\mathrm{Hz}), 4.85-4.98(17 \mathrm{H}$, large singlet and small multiplet), 7.13-7.28 (3.43H, m). ESI-MS: (+) $331.2(\mathrm{M}+1)$. HPLC1: $254 \mathrm{~nm}, t_{\mathrm{R}} 5.27 \mathrm{~min}$, purity $41 \%$.

5-(4-Amino-butyl)-3-(1-hydroxy-ethylidene)-1-(4-methoxy-benzyl)-pyrrolidine-2,4dione (5e). To $0.56 \mathrm{~g}(0.13 \mathrm{mmol})$ of $4 \mathbf{e}$ were added $2 \mathrm{~mL} \mathrm{THF}$ and $0.5 \mathrm{~mL}$ TFA. The reaction was stirred for 1.5 hours at $r$. t., then evaporated. The product was then reacted a second time with $1 \mathrm{~mL}$ THF and $0.5 \mathrm{~mL}$ TFA for $1 \mathrm{~h}$, then evaporated to form a brown sticky semisolid. ${ }^{1} \mathrm{H}$ NMR (500 MHz, CD $\left.{ }_{3} \mathrm{OD}\right): 0.92(0.94 \mathrm{H}, \mathrm{t}, J=6.75 \mathrm{H}), 1.08-1.26$ $(2.42 \mathrm{H}, \mathrm{m}), 1.26-1.38(8.28 \mathrm{H}, \mathrm{m}), 1.39-1.46(3.09 \mathrm{H}, \mathrm{m}$, two main peaks $), 1.48-1.63$ $(1.87 \mathrm{H}, \mathrm{m}), 1.73-1.94(1.88 \mathrm{H}, \mathrm{m}), 2.22(0.36 \mathrm{H}, \mathrm{t}, J=8 \mathrm{~Hz}), 2.29(0.38 \mathrm{H}, \mathrm{t}, J=7.5 \mathrm{~Hz})$, 
$2.46(2.38 \mathrm{H}, \mathrm{s}), 2.61(0.17 \mathrm{H}, \mathrm{s}), 2.82(1.2 \mathrm{H}, \mathrm{t}, J=6.75 \mathrm{~Hz}), 2.92-2.98(0.46 \mathrm{H}, \mathrm{m}), 3.23$ $(2 \mathrm{H}, \mathrm{q}, J=7.67 \mathrm{~Hz}), 3.33(1.24 \mathrm{H}, \mathrm{s}), 3.37(1.62 \mathrm{H}, \mathrm{s}), 3.70-3.83(4.18 \mathrm{H}$, single peak amid multiplet), $4.19-4.30(0.86 \mathrm{H}$, mainly doublet at 4.26 and $J=15 \mathrm{~Hz}), 4.85-5.03(8.7 \mathrm{H}$, singlet merged with smaller peaks), $6.91(2 \mathrm{H}, \mathrm{d}, J=7 \mathrm{~Hz}), 7.27(2 \mathrm{H}, \mathrm{d}, J=7.5 \mathrm{~Hz})$. ESIMS: $(+) 333.2(\mathrm{M}+1)$. HPLC4: $254 \mathrm{~nm}, t_{\mathrm{R}} 6.34 \mathrm{~min}$, purity $81 \%$.

\section{Biology}

\section{Microbiological Testing}

The minimum inhibitory concentrations (MICs) of the tetramic acids were determined by incubation in Mueller-Hinton media in 96-well microplates containing doubling dilutions of antibiotic, with bacterial concentration of approximately $10^{5}$ colony-forming units per milliliter. After overnight growth at $37^{\circ} \mathrm{C}$, the $\mathrm{MIC}$ was recorded as the lowest concentration of antibiotic that impeded visible bacterial growth.

\section{Hemolysis Assay}

The hemolytic activity of tetramic acids against mammalian blood cells was tested against horse erythrocytes (BD Biosciences). A stock suspension (10\% vol $/ \mathrm{vol})$ was prepared in phosphate-buffered saline ( $\mathrm{pH}$ 7.2). Before analysis, the stock suspension was diluted to 1 in 20 with saline, and $360 \mu \mathrm{L}$ aliquots were measured into sterile microcentrifuge tubes. Following incubation for $15 \mathrm{~min}$ at $37^{\circ} \mathrm{C}, 40 \mu \mathrm{L}$ of tetramic acid compounds were added to give final concentrations of 100,10 , or $1 \mu \mathrm{g} / \mathrm{mL}$. The antibiotics used as non-hemolytic negative controls, ampicillin and doxycycline, were tested at a concentration of $10 \mu \mathrm{g} / \mathrm{mL}$, whereas the positive control, the detergent TritonX 100 (inducing $100 \%$ lysis), was tested at $0.1 \%$ vol $/ \mathrm{vol}$. After an incubation period of 1 $\mathrm{h}$ at $37^{\circ} \mathrm{C}$, the reaction mixtures were centrifuged and $200 \mu \mathrm{L}$ of supernatant transferred to 96 well flat-bottom microtiter plates. The absorbance of hemoglobin released from cells was determined by $\mathrm{OD}_{540 \mathrm{~nm}}$ readings on a Synergy HT Biotek plate reader. Based on $\mathrm{OD}_{540 \mathrm{~nm}}$ readings, the $\%$ hemolysis was determined as $100 \times\left(\mathrm{OD}_{540}\right.$ of sample $-\mathrm{OD}_{540}$ of sample blank $) /\left(\mathrm{OD}_{540}\right.$ of Triton-X 100 - $\mathrm{OD}_{540}$ of Triton-X blank $)$. 


\section{List of References}

1. Yendapally, R.; Hurdle, J. G.; Carson, E. I.; Lee, R. B.; Lee, R. E., N-Substituted 3acetyltetramic acid derivatives as antibacterial agents. J. Med. Chem. 2008, 51, (5), 1487-1491.

2. Yendapally, R. Diversified chemical synthesis of novel small molecule inhibitors as antibacterial agents. Dissertation, University of Tennessee Health Science Center, Memphis, TN, 2007. UMI No. AAT 3285327.

3. Fleming, A., On the antibacterial action of cultures of a penicillium, with special reference to their use in the isolation of B. influenzae. Brit. J. Exp. Pathol. 1929, 10, 226-236.

4. Gelmetti, C., Local antibiotics in dermatology. Dermatol. Ther. 2008, 21, (3), 187195.

5. Siewert, G.; Strominger, J. L., Bacitracin: An inhibitor of the dephosphorylation of lipid pyrophosphate, an intermediate in the biosynthesis of the peptidoglycan of bacterial cell walls. Proc. Natl. Acad. Sci. U.S.A. 1967, 57, (3), 767-773.

6. Stone, K. J.; Strominger, J. L., Mechanism of action of bacitracin: Complexation with metal Ion and $\mathrm{C}_{55}$-isoprenyl pyrophosphate. Proc. Natl. Acad. Sci. U.S.A. 1971, 68, (12), 3223-3227.

7. Hughes, J.; Mellows, G., Inhibition of isoleucyl-transfer ribonucleic acid synthetase in Escherichia coli by pseudomonic acid. Biochem. J. 1978, 176, (1), 305-318.

8. Martemyanov, K. A.; Liljas, A.; Yarunin, A. S.; Gudkov, A. T., Mutations in the Gdomain of elongation factor $\mathrm{G}$ from Thermus thermophilus affect both its interaction with GTP and fusidic acid. J. Biol. Chem. 2001, 276, (31), 28774-28778.

9. Chopra, I.; Roberts, M., Tetracycline antibiotics: Mode of action, applications, molecular biology, and epidemiology of bacterial resistance. Microbiol. Mol. Biol. Rev. 2001, 65, (2), 232-260.

10. Silverman, J. A.; Perlmutter, N. G.; Shapiro, H. M., Correlation of daptomycin bactericidal activity and membrane depolarization in Staphylococcus aureus. Antimicrob. Agents Chemother. 2003, 47, (8), 2538-2544.

11. Wangun, H. V. K.; Hertweck, C., Epicoccarines A, B and epipyridone: Tetramic acids and pyridone alkaloids from an Epicoccum sp. associated with the tree fungus Pholiota squarrosa. Org. Biomol. Chem. 2007 5, 1702-1705.

12. Burmeister, H. R.; Bennett, G. A.; Vesonder, R. F.; Hesseltine, C. W., Antibiotic produced by Fusarium equiseti NRRL 5537. Antimicrob. Agents Chemother. 1974, 5, (6), 634-639. 
13. Marfori, E. C.; Kajiyama, S.; Fukusaki, E.; Kobayashi, A., Trichosetin, a novel tetramic acid antibiotic produced in dual culture of Trichoderma harzianum and Catharanthus roseus callus. Z. Naturforsch. 2002, 57, (5-6), 465-470.

14. Toda, S.; Nakagawa, S.; Naito, T.; Kawaguchi, H., Bu-2313, a new antibiotic complex active against anaerobes. III. Semi-synthesis of Bu-2313 A and B, and their analogs. J. Antibiot. 1980, 33, (2), 173-181.

15. Siddhikol, C.; Erbstoeszer, J. W.; Weisblum, B., Mode of action of streptolydigin. $J$. Bacteriol. 1969, 99, (1), 151-155.

16. Reusser, F., Tirandamycin: Inhibition of ribonucleic acid polymerase. Infect. Immun. 1970, 2, (1), 77-81.

17. Reusser, F., Tirandamycin: Inhibition of oxidative phosphorylation in rat liver mitochondria. Infect. Immun. 1970, 2, (1), 82-88.

18. Karwowski, J. P.; Jackson, M.; Theriault, R. J.; Barlow, G. J.; Coen, L.; Hensey, D. M.; Humphrey, P. E., Tirandalydigin, a novel tetramic acid of the tirandamycinstreptolydigin type. I. Taxonomy of the producing organism, fermentation and biological activity. J. Antibiot. 1992, 45, (7), 1125-1132.

19. Aoki, S.; Higuchi, K.; Ye, Y.; Satari, R.; Kobayashi, M., Melophlins A and B, novel tetramic acids reversing the phenotype of ras-transformed cells, from the marine sponge Melophlus sarassinorum. Tetrahedron 2000, 56, 1833-1836.

20. Oda, T.; Fujita, A.; Xu, J.; Mochizuki, M.; Ukai, K.; Namikoshi, M., Effects of melophlins on colony formation of chinese hamster V79 cells and IL-8 production in PMA-stimulated HL-60 cells. Mar. Drugs 2007, 5, (1), 1-5.

21. Wang, C. Y.; Wang, B. G.; Wiryowidagdo, S.; Wray, V.; van Soest, R.; Steube, K. G.; Guan, H. S.; Proksch, P.; Ebel, R., Melophlins C-O, thirteen novel tetramic acids from the marine sponge Melophlus sarassinorum. J. Nat. Prod. 2003, 66, (1), 51-56.

22. Schobert, R.; Jagusch, C., An expedient synthesis of 3-acyltetramic acids of the melophlin family from $\alpha$-aminoesters and immobilized $\mathrm{Ph}_{3} \mathrm{PCCO}$. Tetrahedron 2005, 61, 2301-2307.

23. Kaufmann, G. F.; Sartorio, R.; Lee, S. H.; Rogers, C. J.; Meijler, M. M.; Moss, J. A.; Clapham, B.; Brogan, A. P.; Dickerson, T. J.; Janda, K. D., Revisiting quorum sensing: Discovery of additional chemical and biological functions for 3-oxo-Nacylhomoserine lactones. Proc. Natl. Acad. Sci. U.S.A. 2005, 102, (2), 309-314.

24. Ganzle, M. G.; Vogel, R. F., Studies on the mode of action of reutericyclin. Appl. Environ. Microbiol. 2003, 69, (2), 1305-1307. 
25. Rosen, T.; Fernandes, P. B.; Marovich, M. A.; Shen, L.; Mao, J.; Pernet, A. G., Aromatic dienoyl tetramic acids. Novel antibacterial agents with activity against anaerobes and staphylococci. J. Med. Chem. 1989, 32, (5), 1062-1069.

26. Schobert, R.; Dietrich, M.; Mullen, G.; Urbina-Gonzalez, J.-M., Phosphorus ylide based functionalizations of tetronic and tetramic acids. Synthesis 2006 22, 3902-3914.

27. Lacey, R. N., Derivatives of acetoacetic acid. Part VII. $\alpha$-Acetyltetramic acids. $J$. Chem. Soc. 1954, 850-854.

28. Ley, S. V.; Smith, S. C.; Woodward, P. R., Further reactions of $t$-butyl-3oxobutanthioate and $t$-butyl-4-diethylphosphono-3-oxobutanthioate: Carbonyl coupling reactions, amination, use in the preparation of 3-acyltetramic acids and application to the total synthesis of fuligorubin A. Tetrahedron 1992, 48, (6), 11451174.

29. Lee, V. J.; Branfman, A. R.; Herrin, T. R.; Rinehart, K. L., Jr., Synthesis of 3-dienoyl tetramic acids related to streptolydigin and tirandamycin. J. Am. Chem. Soc. 1978, $100,(13), 4225-4236$.

30. Boeckman, R. K., Jr.; Perni, R. B.; Macdonald, J. E.; Thomas, A. J., 6Diethylphosphonomethyl-2,2-dimethyl-3,1-dioxen-4-one. Organic Syntheses 1988, 66, 194-202.

31. Matthews, J.; Rivero, R. A., Stereospecific synthesis of N-protected statine and its analogues via chiral tetramic acid. J. Chem. Soc., Perkin Trans. 1 1987, 1177-1182.

32. Jouin, P.; Castro, B.; Nisato, D., Stereospecific synthesis of N-protected statine and its analogues via chiral tetramic acid. J. Chem. Soc., Perkin Trans. I 1987, 11771182 .

33. Melanophy, C. Keteneylidenetriphenylphosphorane as a " $\mathrm{C}_{2} \mathrm{O}$ building block" in the synthesis of highly functionalised tetramic and tetronic acids. Dissertation, University of Bayreuth, Bayreuth, 2004. http://opus.ub.uni-bayreuth.de/volltexte/2004/114/ (Accessed October 25, 2008).

34. Hori, K.; Arai, M.; Nomura, K.; Yoshii, E., An efficient 3(C)-acylation of tetramic acids involving acyl migration of 4(O)-acylates. Chem. Pharm. Bull. 1987, 35, 43684371.

35. Ganzle, M. G.; Holtzel, A.; Walter, J.; Jung, G.; Hammes, W. P., Characterization of reutericyclin produced by Lactobacillus reuteri LTH2584. Appl. Environ. Microbiol. 2000, 66, (10), 4325-4333.

36. Holtzel, A.; Ganzle, M. G.; Nicholson, G. J.; Hammes, W. P.; Jung, G., The first low molecular weight antibiotic from lactic acid bacteria: Reutericyclin, a new tetramic acid. Angew. Chem. Int. Ed. Engl. 2000, 39, (15), 2766-2768. 
37. Böhme, R.; Jung, G.; Breitmaier, E., Synthesis of the antibiotic (R)-reutericyclin via Dieckmann condensation. Helvetica Chimica Acta 2005, 88, 2837-2841.

38. Rakesh; Sun, D.; Lee, R. B.; Tangallapally, R. P.; Lee, R. E., Synthesis, optimization and structure-activity relationships of 3,5-disubstituted isoxazolines as new antituberculosis agents. Eur. J. Med. Chem. 2008. In press.

39. Schobert, R.; Schlenk, A., Tetramic and tetronic acids: An update on new derivatives and biological aspects. Bioorg. Med. Chem. 2008, 16, (8), 4203-4221. 


\section{Vita}

Jason Brett Wilson, born June 14, 1983 in Gadsden, Alabama, completed his undergraduate degree in chemistry at the University of Alabama in 2005. He enrolled in the medicinal chemistry program of the University of Tennessee Health Science Center at Memphis in August of 2005 and completed his master's degree in December of 2008. 